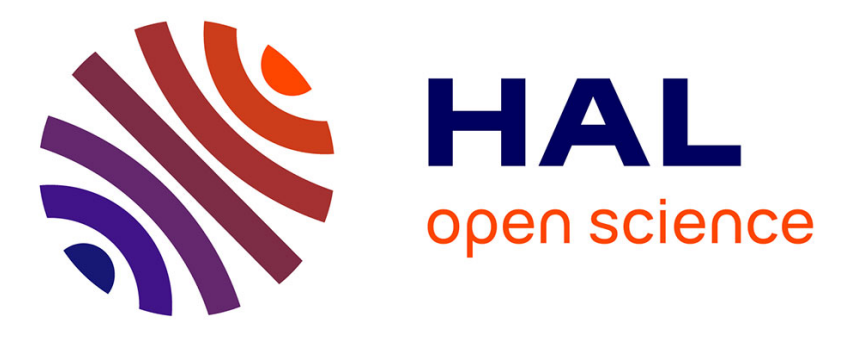

\title{
Veterinary pharmaceutical residues from natural water to tap water: Sales, occurrence and fate
}

Lise Charuaud, Emilie Jardé, Anne Jaffrézic, Marie-Florence Thomas, Barbara Le Bot

\section{- To cite this version:}

Lise Charuaud, Emilie Jardé, Anne Jaffrézic, Marie-Florence Thomas, Barbara Le Bot. Veterinary pharmaceutical residues from natural water to tap water: Sales, occurrence and fate. Journal of Hazardous Materials, 2019, 361, pp.169-186. 10.1016/j.jhazmat.2018.08.075 . insu-01863750

\section{HAL Id: insu-01863750 https://hal-insu.archives-ouvertes.fr/insu-01863750}

Submitted on 29 Aug 2018

HAL is a multi-disciplinary open access archive for the deposit and dissemination of scientific research documents, whether they are published or not. The documents may come from teaching and research institutions in France or abroad, or from public or private research centers.
L'archive ouverte pluridisciplinaire $\mathbf{H A L}$, est destinée au dépôt et à la diffusion de documents scientifiques de niveau recherche, publiés ou non, émanant des établissements d'enseignement et de recherche français ou étrangers, des laboratoires publics ou privés. 


\section{Accepted Manuscript}

Title: Veterinary pharmaceutical residues from natural water to tap water: Sales, occurrence and fate

Authors: Lise Charuaud, Emilie Jarde, Anne Jaffrezic, Marie-Florence Thomas, Barbara Le Bot

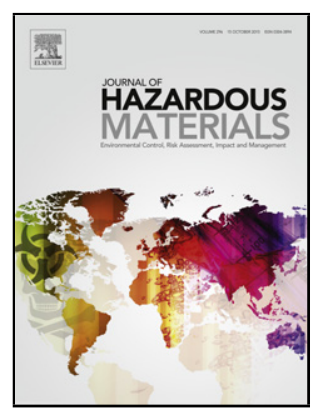

PII: $\quad$ S0304-3894(18)30762-3

DOI: $\quad$ https://doi.org/10.1016/j.jhazmat.2018.08.075

Reference: $\quad$ HAZMAT 19700

To appear in: $\quad$ Journal of Hazardous Materials

Received date: $\quad$ 5-4-2018

Revised date: $\quad 31-7-2018$

Accepted date: $\quad 22-8-2018$

Please cite this article as: Charuaud L, Jarde E, Jaffrezic A, Thomas MFlorence, Le Bot B, Veterinary pharmaceutical residues from natural water to tap water: Sales, occurrence and fate, Journal of Hazardous Materials (2018), https://doi.org/10.1016/j.jhazmat.2018.08.075

This is a PDF file of an unedited manuscript that has been accepted for publication. As a service to our customers we are providing this early version of the manuscript. The manuscript will undergo copyediting, typesetting, and review of the resulting proof before it is published in its final form. Please note that during the production process errors may be discovered which could affect the content, and all legal disclaimers that apply to the journal pertain. 


\section{Veterinary pharmaceutical residues from natural water to tap water: Sales, occurrence and fate}

Lise Charuaud $^{\mathrm{a}^{*}}$, Emilie Jarde ${ }^{\mathrm{b}}$, Anne Jaffrezic $^{\mathrm{c}}$, Marie-Florence Thomas ${ }^{\mathrm{a}}$, Barbara Le Bot ${ }^{\mathrm{a}}$

${ }^{a}$ Univ Rennes, Inserm, EHESP, Irset (Institut de recherche en santé, environnement et travail)

- UMR_S 1085, F-35000 Rennes, France

bUniv Rennes, CNRS, Géosciences Rennes - UMR6118, 35000 Rennes, France

'UMR SAS, Agrocampus Oust, INRA 35000 Rennes, France

*Corresponding author:

E-mail address: $\underline{\text { lise.charuaud@ehesp.fr }}$

Postal address: EHESP/LERES, 15, avenue du Pr. Léon-Bernard, CS 74 312, 35043 Rennes

cedex, France

Tel.: +33 (0)2 99022705 .

Graphical abstract

Veterinary pharmaceutical residues from natural water to tap water
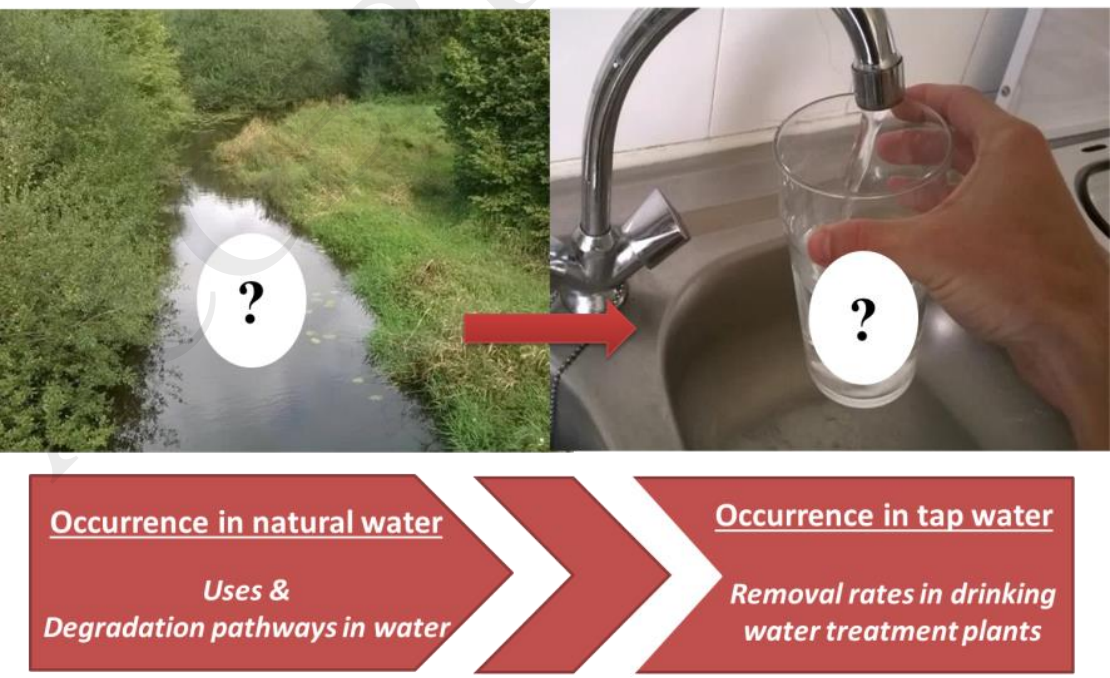


\title{
HIGHLIGHTS
}

- Worldwide, tetracyclines are the most sold veterinary pharmaceuticals

- Photolysis is the main degradation pathway of veterinary residues in surface waters

- Veterinary drugs concentrations in natural waters range from $1 \mathrm{ng} . \mathrm{L}^{-1}$ to $255 \mu \mathrm{g} . \mathrm{L}^{-1}$

- Overall removal rates in drinking water treatment plants generally exceed $90 \%$

- 11 studies on the occurrence of veterinary pharmaceutical residues in tap water

\begin{abstract}
Veterinary pharmaceuticals (VPs) increasingly used in animal husbandry have led to their presence in aquatic environments -surface water (SW) or groundwater $(\mathrm{GW})$ - and even in tap water. This review focuses on studies from 2007 to 2017. Sixty-eight different veterinary pharmaceutical residues (VPRs) have been quantified worldwide in natural waters at concentrations ranging from nanograms per liter $\left(n g . \mathrm{L}^{-1}\right)$ to several micrograms per liter $\left(\mu \mathrm{g} . \mathrm{L}^{-1}\right)$. An extensive up-to-date on sales and tonnages of VPs worldwide has been performed. Tetracyclines (TCs) antibiotics are the most sold veterinary pharmaceuticals worldwide. An overview of VPRs degradation pathways in natural waters is provided. VPRs can be degraded or transformed by biodegradation, hydrolysis or photolysis. Photodegradation appears to be the major degradation pathway in SW. This review then reports occurrences of VPRs found in tap water, and presents data on VPRs removal in drinking water treatment plants (DWTPs) at each step of the process. VPRs have been quantified in tap water at ng. $\mathrm{L}^{-1}$ concentration levels in four studies of the eleven studies dealing with VPRs occurrence in tap water. Overall removals of VPRs in DWTPs generally exceed $90 \%$ and advanced treatment processes (oxidation processes, adsorption on activated carbon, membrane filtration) greatly contribute to these removals. However, studies performed on full-scale DWTPs are scarce. A large majority of fate studies in DWTPs have been conducted under laboratory at environmentally irrelevant conditions (high concentration of VPRs (mg. $\mathrm{L}^{-1}$ ), use of deionized water instead of natural water, high concentration of oxidant, high contact time. etc.). Also, studies on VPRs occurrence and fate in tap water focus on antibiotics. There is a scientific gap on the occurrence and fate of antiparatic drugs in tap waters.
\end{abstract}

Abbreviations*

${ }^{*}$ VPs: Veterinary pharmaceuticals VPRs: Veterinary pharmaceutical residues

\section{KEY WORDS}

Veterinary drugs; antibiotics; animal husbandry; drinking water treatment plant; removal rates.

\section{INTRODUCTION}


As the human population is growing, animal production is also rapidly expanding to feed this population [1]. This leads to intensive agricultural practices, with confined animal feeding operations (CAFOs) [2,3]. In CAFOs, it is a common practice to use veterinary pharmaceuticals (VPs) not only for curative ends, but also prophylactic purposes $[1,4,5]$.VPs have also been widely used for growth promotion [4], even if this practice has begun to be restricted or even banned, for example in the European Union (EU) [6,7]. Nowadays, more than 2000 veterinary pharmaceuticals products are available on the market worldwide [8]. VPRs can be released into the environment either directly with urine and feces of animals in pastures or during aquaculture activities, or indirectly during the spreading of contaminated manure and slurry [7,9-12]. Because of their continuous use, veterinary pharmaceutical residues (VPRs) represent a diffuse and pseudo-persistent pollution in the environment. Among other emerging contaminants, VPRs have been quantified worldwide in aquatic environment, with progresses in analytical methods $[10,13,14]$. As tap water is produced worldwide from natural waters (SW or GW), it is important to review the occurrence of VPRs in natural waters and the factors affecting this occurrence. Indeed VPRs occurring in natural waters may reach DWTPs which produce tap water. A public health concern is that if these compounds are not fully removed and/or transformated in DWTPs, the human population could be chronically exposed to these compounds. This continuous exposure may represent a risk as VPs are designed to exert biological effects on animals at low doses (as for antibiotic which are active at $\mathrm{mg}$ of drug per $\mathrm{kg}$ of animal weight) or very low doses (hormones which are active at $\mu \mathrm{g}$ of drug per $\mathrm{kg}$ of animal weight) [12]. VPR may also interact together or with other organic contaminants present in drinking water, resulting in addition or synergistic effects [12]. Moreover, chronic exposure of pathogens, commensal or environmental bacteria to veterinary antibiotics can lead to cross- resistance to antibiotics through the development and selection of more harmful bacteria $[12,15]$. It is a crucial issue as no new class of antibiotics has been discovered since 1987 [8].

However, data on VPRs fate in DWTPs as well as on their occurrence in tap water are scarce and deserve more attention as it is not known if those micropollutants are removed during the applied treatment processes. Lastly, transformation products (TPs) of VPRs should also be considered. Subsequent compounds generated after the transformation process of a certain "parent compound" are considered as TPs. TPs can be generated by natural processes such as metabolization in the treated animals $[7,11,16]$ or via hydrolysis or photolysis in the environment [17-19]. They can also be derived from engineering processes, for example during agricultural waste management practices (i.e. digestion, composting, etc.,) $[5,20]$ or in DWTPs during oxidation steps [12,21,22]. These TPs can retain a biological activity $[21,23,24]$ which may pose risks towards aquatic ecosystems or human health.

Ciprofloxacin is the main metabolite of the veterinary antibiotic enrofloxacin, and it is also a pharmaceutical used in human medicine. Both compounds have been proved to exert a negative impact on amphibian larvae growth and development at concentrations greater than or equal to $10 \mu \mathrm{g} . \mathrm{L}^{-1}$ [25]. Photo-transformation products of the antibiotic tetracycline exhibit a higher toxicity towards luminescent bacteria V. fischeri than tetracycline [26] and photoproducts of the hormone altrenogest seem to possess significant androgenic activity according to in vitro tests performed by Wammer et al. [27]. Thus aquatic ecosystems can be negatively impacted by TPs generated by VPRs. When considering TPs produced during tap water production, TPs can gain toxicity during oxidation processes [28,29]. TPs of nitroimidazoles compounds generated during ozonation process were more toxic to $\mathrm{V}$. fischeri than the initial nitro-imidazoles [29]. In Leavey-Roback et al. [28], chloramination disinfection of veterinary antiobiotics such as tetracyclines or macrolides induces the formation of the carcenogenic disinfection product $\mathrm{N}$-nitrosodimethylamine. Thus, these TPs may threat human health. 
Many reviews have been published on veterinary pharmaceutical residues in the environment [4,6-9,12,15,16,30-44]. In those reviews, veterinary pharmaceutical residues occurrence and fate in soil have been largely studied, as mobility from soil to water. But only few reviews have been published on occurrence and fate in natural waters (sorption and degradation) and tap water. This review provides an update on research performed from 2007 to 2017 on (1) the occurrence of 65 VPRs (i.e. antibiotics, antiparasitic drugs, anti-inflammatory drugs) in natural waters (surface water and groundwater; 38 studies) related to (2) their uses and their fate. An extensive up-to-date on sales data worldwide, ten years after Sarmah et al., publication [38] is provided, as sales and usages are critical factors impacting environmental occurrence of VPRs [45-47]. Sales trends over the past decade are presented for countries where they are available in the public domain. It is also mention when there is no available sales information for countries which are likely to be significant consumers of VPRs. In 2009, Kümmerer [35] reported a lack of information on VPRs degradation pathways, especially on photolysis, with comparison between direct and indirect photolysis. To fill this gap, a complete and up-to-date overview of degradation pathways by chemical family is provided (38 studies). Afterwards, this review focus on (3) VPRs occurrence in tap water (11 studies) consequently to (4) their behaviour during drinking water treatment plant processes (28 studies).

Few reviews address VPRs behaviour in DWTPs, and deal with pharmaceuticals and personal care products with great emphasis on human pharmaceuticals $[23,48]$ or with antibiotics used both in human and veterinary medicine $[32,49]$. To our knowledge, this review is the first to gather all available data on VPRs removals rates and fate in DWTPs.

\section{OCCURRENCE OF VPRS IN NATURAL WATERS}

The occurrences of VPRs (since 2007) in surface water and groundwater are presented in Figure 1 and Figure 2. Figure 1 focuses on VPRs that have been searched in more than one hundred samples (all studies included). The minimum and maximum quantified concentrations of VPRs in each study are shown on the graphic. Figure 2 focuses on VPRs searched in less than one hundred samples and shows minimum and maximum concentrations quantified in each study. VPRs that were investigated but not detected have not been reported in Figures 1 and 2, for example coccidiostat toltrazuril and its metabolites [50], avermectins [51] or some corticosteroids $[13,14]$.

In the 38 studies considered [2,13,14,45-47,51-84], sampling was carried out near husbandry facilities or crops in rural watersheds, once or several times at different seasons of the year.

[Figure 1]

[Figure 2]

As reported in Figure 1 and 2, 64 different VPRs were detected in surface waters, especially rivers $[59,61,63,64]$ but also lakes $[55,58]$, at concentrations ranging from $<1 \mathrm{ng} . \mathrm{L}^{-1}$ $[58,68,72]$ to 255 microgram. $\mathrm{L}^{-1}\left(\mu \mathrm{g} . \mathrm{L}^{-1}\right)$ (tetracycline [83]; out-of-scale value in Figure 1). High levels of concentrations depend on the study location and of the veterinarian prescriptions in the corresponding area. For example, the highest concentration level (tetracyline; $255 \mu \mathrm{g} . \mathrm{L}^{-1}$ ) was quantified in a sampling site that was assumed to be affected by the discharge of veterinary pharmaceuticals from a swine manure composting facility [83]. Sulfapyridine, sulfamethazine, sulfamethoxypyridazine and sulfadiazine were quantified in the Llobregat river in Spain at $12 \mu \mathrm{g} . \mathrm{L}^{-1} ; 6192$ ng. $\mathrm{L}^{-1} ; 3704$ ng. $\mathrm{L}^{-1}$ and 2312 ng. $\mathrm{L}^{-1}$, respectively. Similarly, many agricultural areas were located upstream the sampling site [67]. In the 11 studies considered in groundwater, 47 VPRs were quantified with concentrations ranging from $<1 \mathrm{ng} . \mathrm{L}^{-1}$ [76] to $3.461 \mu \mathrm{g} . \mathrm{L}^{-1}$ for sulfacetamide [79]. Sulfonamides (SAs) 
constitute the most detected chemical family but also the most studied (28 studies on 38 studies considered) so there may be a bias. Surface water can be a source of contamination for groundwater through artificial or natural exchanges between the two resources $[46,59,85]$.

\section{FACTORS IMPACTING THE OCCURRENCE OF VPRS IN NATURAL}

\section{WATERS}

\subsection{Sales and uses of VPs worldwide}

Uses of VPs strongly differ between countries, because of the different animal species (i.e. swine, cattle, sheep, etc.), animal farming methods and climate conditions $[9,62]$. However, the therapeutic classes most often used are antibiotics, antiparasitics (endo- and ectoparasitics) and steroidal hormones [9,12]. Antibiotics represent $70 \%$ of all consumed drugs that are approved for animal medicine worldwide [11]. Other therapeutic classes used in veterinary medicine include non-steroidal anti-inflammatory drugs, anxiolytics and sedatives such as benzodiazepines, beta-agonists agents, anesthetics, euthanasia products, antacids, diuretics, emetics, etc. [12].

In 2006, [38] provided an international overview of veterinary antibiotics sales by compiling available information at that time. Based on this previous work, an up-to-date of the sales was performed in order to show new trends in these uses and determine evolutions in data availability. In 2006, sales data were not available in the United States of America (USA) and only a few European countries (Sweden, Denmark, Finland, and Netherlands) were publishing their antibiotic sales in the public domain [38]. Current available sales data, i.e. about ten years after [38], are presented below.

Tables 1; 2 and 3 report the latest available sales amounts for USA (2016), Europe (2015), France (2016), Japan (2015), Korea (2015), New Zealand (2014) and Australia (2010).

According to the tables 1; 2 and 3, the most frequently used antibiotics worldwide for veterinary purposes are tetracyclines (TCs), SAs, penicillins (PENs) and macrolides (MLs).

[Table 1]

In the USA, the amount of antibiotics sold for veterinary purposes equals $70 \%$ of total antibiotics sales $[1,3,6,86]$. An increase of $11 \%$ in total annual sales amount was reported between 2009 and 2016, but sales decreased by $10 \%$ between 2015 and 2016 [87]. Sales of lincosamides and cephalosporins increased by more than 50\% between 2009 and 2016 [87]. Total amount of antibiotics for veterinary use was estimated at almost 13983 tons in 2016 [87], perhaps the world's largest (or second behind China [3,88]). These high amounts are not only due to the presence of large numbers of livestock, but also to the authorized use of antibiotics as growth promoters [12]. High use of ionophores is largely responsible for quantification of monensin in surface water (300 to 5130 ng.L $\mathrm{L}^{-1} ;$ [70,71]), salinomycine (9022 ng. $\left.\mathrm{L}^{-1} ;[71]\right)$ and narasin (348 ng. $\mathrm{L}^{-1} ;$ [71]) but also in groundwater (monensin, 20 to 2950 ng. $\left.L^{-1} ;[2,81]\right)$.

Canada also has a large and dynamic animal food production industry [38] and is reported to have a widespread use of veterinary antibiotics [86]. However, data on veterinary pharmaceuticals sales in Canada are still not available in the public domain.

Since 2010, the European Surveillance of Veterinary Antimicrobial Consumption (ESVAC) releases an annual report of antimicrobials sales, currently including data from 30 European countries, including France. Total antimicrobials sales were 8361 tons in 2015 according to 
the latest report [89]. Prevalent families differ from those in the USA. However, ionophores, which constitute the second most sold family of compounds in the USA, are not included in the ESVAC report. Indeed, in Europe these compounds are no longer used as feed additives because growth promoters have been banned since 2006 [90]. This may explain the differences observed between Europe and USA sales.

In 2015, the highest antimicrobial sales were reported for Spain with 3030 tons, Italy with 1310 tons and Germany with 858 tons [89]. Between 2011 and 2015, the general trend was a $13 \%$ decrease in veterinary antibiotics sales in Europe (25 countries included). Some countries included in the ESVAC report also publish individual detailed annual reports of their antibiotics sales such as France [91] or United-Kingdom [92].

In 2006 [38], sales amounts of veterinary pharmaceuticals were lacking in Asia. Ten years later, even though veterinary antibiotics uses are regulated in China, there is currently no official governmental report on sales amounts [88,93], while some previous studies suggest that China may be the first consumer of veterinary antibiotics in the world $[1,3,6]$. Nevertheless, limited available data suggest 210,000 tons of antibiotics are produced annually, with $46 \%$ of this tonnage used for food-producing animals [93,94].

Furthermore, to our knowledge, India, Indonesia or Thailand are still neither reporting any information on veterinary pharmaceutical types or amounts used.

[Table 2]

On the other hand, as shown in Table 2, reports have been released in South Korea [95], and in Japan [96]. To our knowledge, Japan is the only country worldwide reporting the sales of antiparasitic drugs (antihelmintics and antiprotozoals). The most sold antiparasitic drugs are fenbendazole and praziquantel with about 3 tons, ranking $22^{\text {nd }}$ and $23^{\text {rd }}$ in veterinary sales amounts. Between 2007 and 2015, VPs sales in Japan decreased by 11\%, with 879 tons in 2007 [97] and 788 tons in 2015 [96]. In Korea, overall sales of antibiotics (including anticoccidians) have also gradually decreased, with 1527 tons sold in 2007 and 910 tons in 2015 [95]. However, phenicols and cephalosporins sales have been multiplied by 3 and 5, respectively [95]. Occurrence of oxytetracycline (390 to $\left.1410 \mathrm{ng} . \mathrm{L}^{-1},[61]\right)$, chlortetracycline (13 to 793 ng. $\left.L^{-1},[61,63]\right)$, tylosin (230 to 2190 ng.L ${ }^{-1}$, Ok et al., 2011), florfenicol (17 to 340 ng. $\mathrm{L}^{-1}$; [63]) and enrofloxacin (10 to $133 \mathrm{ng} . \mathrm{L}^{-1}$, [63]) in Korean surface waters can be explained by the fact that those compounds are among the top ten sellers in the country. On the contrary, tetracycline, which has been quantified at $255 \mu \mathrm{g} . \mathrm{L}^{-1}$ [83], is not included in the top ten sellers of Korea. In Japan, oxytetracycline, the most sold compound, was quantified at 68000 ng.L ${ }^{-1}[65]$.

[Table 3]

New Zealand and Australia both reported zinc bacitracin as the most sold compound. Zinc bacitracin is used for the treatment and prevention of necrotic enteritis in poultry, and is administered in the feed. In Australia, there were no significant change in the total amount of antibiotics sold between 2005 and 2010. Growth promotants accounted for 4\% to $7 \%$ of total antimicrobials sold for use in food animals [98]. In New Zealand, antibiotic sales increased by 13\% between 2010 and 2014. Sales of TCs and cephalosporins increased by 57\% and 36\%, respectively [99].

It has to be considered that tonnages may not be an adequate parameter to assess the actual use pattern of VPs. In addition, increasing or decreasing sales trends over time may reflect usage changes, but it may also be representative of changes in animal populations across the country. To eliminate of this bias, a population correction unit [89] is used or a ratio of the active ingredient sold (mg) per kilogram of animal bodyweight is applied [91,92].

Within a country, uses of VPRs vary throughout the year. In winter, livestock tend to be more sensitive to pathogens and prophylactic treatments are increased to prevent respiratory 
diseases or other epidemics in herds [65]. Some exceptions may be noted, such as a common indication of SAs for bacterial or protozoal infections occurring in summer.

\subsection{Fate of VPRs in natural waters}

This part of the review considers the behaviour of VPRs in natural waters- transfer and sorption to sediment, and degradation pathways - which will affect concentration levels in natural water. Beyond sorption and degradation, climate and weather strongly influence VPRs concentrations in natural waters with heavy rainfall resulting in higher flow rate and significant dilution of VPRs in the waterbodies [54,57].

2.2.1. Partitioning and sorption

VPRs are found in different fractions of water: soluble fraction, colloidal fraction or particular fraction $[45,100,101]$. Ionic and hydrophobic interactions known to occur between VPRs and soil $[7,8,10,11,16,35,44,102,103]$ will apply for the partitioning between VPRs and the different fractions: colloids, solid particulate matter (SPM) and sediment. To determine the partitioning behaviour and the dynamics of VPRs between the different phases (i.e. soluble, colloidal, SPM, sediment), the calculation of a pseudo-partition coefficient $(P-P C)$ is useful $[104,105] .(P-P C)$ is calculated as the ratio of the VPR concentration in the studied solid phase (either colloidal, SPM or sediment) to the corresponding concentration in the water phase (soluble).

Calculated P-PCs between water and SPM are presented in table 4 [45,101], and table 5 identified some of the $P-P C$ between sediment and water phase calculated for veterinary antibiotics $[45,53,57,104-108]$.

[Table 4]

[Table 5]

Table 4 and 5 show that means $P$-PCs water -SPM and P-PCs water-sediment for antibiotics increase in the following order: SAs and MLs $\left(10^{2}\right.$ order) < TCs (up to $\left.10^{3}\right)<$ fluoroquinolones (FQs) (up to $10^{4}$ ). As expected, TCs and FQs have a stronger binding capacity to solid fractions (sediments and SPM) than SAs [100,101,106,107], as in soils. FQs tend to be more persistent than MLs once in sediments [100] and have a higher tendency to accumulate in sediments than TCs [108]. As SAs, trimethoprim, lincomycin and florfenicol tend to be distributed only in the aqueous phase [109].

Thus, sediment constitute an important sink but also a potential secondary source for VPRs, which can be released in water through sorption-desorption and re-suspension processes $[53,105,106,108,109]$. However, no significant seasonal variations of SAs, MLs, TCs and FQs concentrations in the sediment were reported in [100,107].

Sorption will also influence VPRs transport into groundwaters. As VPRs are mostly ampholytic compounds, a retardation of their transport in groundwaters can be expected because of ion sorption dominated by electrostatical interactions [110].

\subsubsection{Degradation in water}

In water, VPRs can be degraded and/or transformed through biotic (biodegradation) or abiotic (hydrolysis or photolysis) processes. These degradation mechanisms are more efficient during dry seasons, as a rise in temperature promotes microbial activity and photolysis $[46,47,55]$.

Photolysis is an important degradation pathway of VPRs in surface water [17,26]. VPRs can undergo direct photolysis with direct absorbance of photons [111] if there is an overlap between the irradiation spectrum and the absorption spectra of the molecule [112]. VPRs that 
do not absorb light at $\lambda>290 \mathrm{~nm}$ do not undergo direct photolysis [111,112]. VPRs can also be subjected to indirect photolysis or even self-sensitized photo-oxidation [113].

Indirect photolysis is induced by light absorption of components from dissolved organic matter (DOM) or nitrates [26,111]. The components will generate various reactive species of oxygen (ROS), such as light excited DOM, hydroxyl radical, peroxyl radicals, singlet oxygen, and superoxide [18]. ROS can react with VPRs and increase their degradation [19]. However, DOM can also prevent photolysis of VPRs by screening sunlight [18,19,114], by competitive absorption of solar radiations [17], by quenching ROS [18,19], or by adsorbing VPRs themselves [112]. In the end, indirect photolysis of VPRs will depends of the balance of each opposite contribution of DOM (i.e. photosensitizing and/or inhibiting photolysis) [17]. Selfsensitized photo-oxidation is a process in which photo-sensitized organic compounds may produce reactive singlet oxygen via the energy transfer from the light-excited triplet state of the molecule to ground state.The reactive singlet oxygen will then transform and/or degrade the organic compound by oxidation [111]. TCs, ionophores and phenicol antibiotics, are subjected to self-sensitization photo-oxidation [19,111,115]. For phenicols, the photooxidation occurs on the carbon atoms and generate isomers of the parent compounds [111].

Table S3 presents the photolysis tests performed under experimental conditions close to environmental conditions. For example, experiments performed in freshwater are preferred to experiments performed in deionized water. Likewise, experiments performed under sunlight are preferred to experiments performed in artificial light. When the study is performed on deionized water, only direct photolysis is estimated. Both direct and indirect photolysis is evaluated on freshwater, due to the presence of DOM.

Several parameters will influence the photolysis rate of VPRs such as VPR concentration levels $[26,114,116]$, water $\mathrm{pH}[17,27,116-118]$, ionic species (i.e. nitrates, phosphates, divalent cations as $\left.\mathrm{Ca}^{2+}\right)[17,19,26,113,116,119,120]$, composition and concentration of DOM [18,19,26,121], light intensity [116] and depth of natural waters [19].

Besides, VPRs can be biodegraded and/or biotransformed by bacteria [122-125] or fungi present in water. However, fungi do not usually have a great role in degradation of pharmaceuticals in the aquatic environment [126]. Concerning steroidal hormones, although data are lacking, it has been suggested that they are subjected to biodegradation [34], and biodegradation of antiparasitic drugs in soil has been reported [34]. Thus, it can be assumed that biodegradation is also likely to occur in aquatic environment.

Hydrolysis is also a common reaction leading to abiotic degradation of substances in the aquatic environment [127]. VPRs may either be stable in water or rapidly hydrolyzed.

Table 6 summarizes the degradation pathways reported by literature for the studied chemical families. These studies focus on degradation pathways of antibiotics including ionophores. Data on the environmental behaviour of antiparasitic drugs in water is missing in the literature.

[Table 6]

According to Table 6, only SAs are reported to be subjected to biodegradation, while hydrolysis has been observed for PENs, cephalosporins and TCs. Photolysis appears to be the major degradation/transformation pathway of VPRs in natural waters. Moreover, according to the half-lives reported in Table 6, photolysis degradation of VPRs is also occurring faster than hydrolysis and biodegradation of VPRs.

Multiple transformation products can be generated during the degradation of parent compounds $[17-19,120,128]$. Photolysis of fluoroquinolones leads to the formation of 5 and 2 photo-transformation products for enrofloxacin and marbofloxacin respectively [17], while photolysis of the SAs sulfadimethoxine, sulfamethazine and sulfamethoxypyridazine generated 11, 8 and 6 transformation products, respectively [18,128,129]. These TPs can be more stable than the parent compounds as it was observed with sulfamethoxypyridazine and 
sulfathiazole photo-degradation products for example $[129,130]$. Also TPs may still exercise a biological activity or even be more toxic to the ecosystems than the parent compound $[26,119,128]$. The antimicrobial-active transformation products 4 -Epi-, $\alpha$-apo-, and $\beta$-apooxytetracycline were identified during hydrolysis of oxytetracycline [120]. Altrenogest photoproducts exhibit an androgenic activity comparable to that of altrenogest [131]. However TPs can also be inactive, as TPs generated during the photolysis of the ionophore salinomycine or the aminoglycoside streptomycin $[19,112]$.

\section{OCCURRENCE OF VPRS IN TAP WATER}

There is an evident lack of data on the occurrence of VPRs in tap water, as shown in table 7, which includes only four studies from 2007 to 2017 [82,132-134].

[Table 7]

Due to this limited number of studies on VPRs in tap water (11 studies), the studies locations are not specifically rural areas with livestock activities nearby. All studies analyzing at least one VPR in tap water were taken into account. Neverthless, VPRs have been quantified in tap water at lower concentrations than in water resources (both SW and GW), from 2 ng.L $\mathrm{L}^{-1}$ [132] to a maximum of 104 ng.L $\mathrm{L}^{-1}$ [133]. In China, 6 VPRs were quantified in the 113 tap waters sampled in 13 cities, up to 104 ng. $\mathrm{L}^{-1}$ for thiamphenicol [133]. During a national survey conducted in France on 285 samples, only 3 of the 12 investigated compounds were detected [82].

Besides the studies mentioned in table 7 , a few other studies have investigated VPRs in tap water but without detecting any [135-141].

\section{FATE OF VPRS IN DRINKING WATER TREATMENT PLANTS}

In DWTPs, the VPRs are subjected to the same or very similar processes that they face in water resources. Thus, their fate and behaviour in DWTPs depends on the same physical or chemical reactions as in the environment (i.e. adsorption, oxidation, biodegradation). Nowadays, DWTPs are not designed to treat VPRs, but because some VPRs have similar physicochemical properties (polarity, molecular weight) to other micropollutants (pesticides for example), some of them can be removed. For example, the use of membranes with molecular weight cut-off varying between 200 and $400 \mathrm{Da}$ is generally appropriate for pesticides removal [142]. These results can be compared with nanofiltration removal efficiencies observed by Dolar et al. [143] for VPRs such as febantel and ciprofloxacin.

For the production of tap water from surface water with high total organic carbon concentration, the average DWTP has a clarification process, preceded or followed by advanced treatment processes (i.e. activated carbon, oxidation, membranes filtration). The last step is disinfection. A scheme of a DWTP is succinctly represented in Figure 3. Each treatment step is described in details in the corresponding section below.

[Figure 3]

The table 8 summarizes removal rates for some VPRs reported during the different DWTPs steps. The considered studies were mostly conducted at laboratory scale, thus the parameters used vary from one study to another (i.e. VPR concentration, oxidant concentration, contact 
time etc.) and may not be representative of full-scale DWTP conditions. The main bias in laboratory studies is the VPRs concentration. For example, in studies reported on VPRs adsorption on activated carbon, VPRs concentrations vary from $5 \mu \mathrm{g} . \mathrm{L}^{-1}$ [144] to $600 \mathrm{mg} . \mathrm{L}^{-1}$ [145], which are not representative of environmental concentrations. To compare, in a study performed on full-scale DWTP [135], the reported concentration of the antibiotic erythromycin in the influent prior to filtration on activated carbon was included between 0.8 and 1.4 ng... . $^{-1}$

[Table 8]

\subsection{Clarification}

Clarification consists of several steps: coagulation, flocculation, sedimentation and sand filtration [146]. Clarification aims at reducing turbidity and total organic carbon by removing particulate matter and colloids [147]. The main parameters that control clarification process are the coagulant/floculant types and amounts, $\mathrm{pH}$ [146]. As VPRs can be adsorbed onto particulate matter and colloids, they may be removed during the clarification process, depending on their physicochemical properties (log Kow and pkas) [147]. TCs are amphoteric compounds which possess three pkas and they are known to bind on particulate matter and colloids by ionic exchanges in raw water. Coagulation of seven TCs was studied on river water at lab-scale, with aluminum polychloride as coagulant [148]. Coagulation was effective to remove TCs with optimum removal rates ranged between $47 \%$ and $66 \%$ for an incoming concentration of $100 \mu \mathrm{g} / \mathrm{L}$ of TCs and $60 \mathrm{mg} / \mathrm{L}$ of coagulant. However, most studies indicate that clarification steps alone poorly remove VPRs $[28,48,144,149-151]$, for any operating conditions.

\subsection{Advanced treatment technologies}

Oxidation processes, adsorption on activated carbon, and membrane filtration processes (ultrafiltration, nanofiltration) are classified as advanced treatment technologies and are mainly used on raw surface water [146].

\subsubsection{Oxidation processes}

Pre-oxidation can be performed as first step of the process, using either $\mathrm{KMnO}_{4}$, chlorinederived species, or ozone $\left(\mathrm{O}_{3}\right)$. The aim of pre-oxidation is to eliminate mineral compounds such as iron or manganese, which can modify the color and taste of water, but also algae [152]. An intermediate oxidation step sometimes takes place after clarification using $\mathrm{O}_{3}$ only. Its goal is to enhance the degradation of micropollutants and residual organic matter. Finally, oxidation is performed for a third time as the last step in the whole treatment process. It is the disinfection step, which aims to eliminate all micro-organisms before distribution of the treated water. Disinfection can be performed either with $\mathrm{O}_{3}$, chlorine-derived species or ultraviolets (UV) [153]. The oxidant type impacts the process. Ben et al. [154] found that the reaction rates constants of SAs with chlorine dioxide at $\mathrm{pH} 7$ and $20^{\circ} \mathrm{C}$ were higher than with free chlorine, but lower than with ozone under comparable experimental conditions. Besides the oxidant type, the contact time and the dosage of the oxidant is different between preoxidation, intermediate oxidation and disinfection [147]. VPR degradation rate during the oxidation steps will depend on those parameters, with enhanced degradation at higher oxidant doses and through longer contact time. Garoma et al. [151] studied the influence of ozone gas 
concentration on ozonation reaction of four sulfonamides. At 120 seconds of reaction, SAs removal ranged between 90 and $99 \%$ for $3.2 \mathrm{mg} . \mathrm{L}^{-1}$ of ozone gas applied. For the same reaction time, SAs removal ranged between 65 and $80 \%$ when using an ozone concentration of $2.3 \mathrm{mg} . \mathrm{L}^{-1}$. Thus, results showed that the removal of all sulfonamides increased as ozone gas concentration increased [151].

Oxidation processes can lead to the formation of oxidation by-products that may be more toxic than the parent compound. Currently, the formation pathway, the chemical structure and the potential impacts towards human health of those transformation products are largely unknown [21].

\subsubsection{1. $\mathrm{KMnO4}$}

Pre-oxidation can be performed as first step of the process, using potassium permanganate $\left(\mathrm{KMnO}_{4}\right)$, chlorine-derived species, or ozone $\left(\mathrm{O}_{3}\right)$. In a full-scale DWTP, up to $87 \%$ and $89 \%$ of florfenicol and flunixin, respectively, were removed during the pre-oxidation (using $\mathrm{KMnO}_{4}$ ) and coagulation stages (using aluminum polychloride). However, this high removal rate was probably largely due to the pre-oxidation step [155].

\subsubsection{Ozonation}

Ozone has an important reduction potential $(\mathrm{E}=2.07 \mathrm{~V})$, superior to $\mathrm{Cl}_{2}(\mathrm{E}=1.36 \mathrm{~V})$. Consequently, it is a powerful oxidant [156]. It can interact with VPRs either directly or via hydroxyl radicals formed during ozone decomposition at $\mathrm{pH} 7$ or higher $[24,29,151,157]$. SAs (sulfadiazine and sulfamethoxazole) antibiotics and nitroimidazole antibiotics (metronidazole, dimetridazole, tinidazole, ronidazole) had a higher degradation rate when reacting with hydroxyl radical formed during ozone decomposition than when reacting with molecular ozone $[29,157]$. Therefore, the ozone process is usually more efficient at alkaline $\mathrm{pH}$ $[29,151,156]$. An exception was noted in [24], where sulfaquinoxaline degraded faster and more efficiently ( $99 \%$ in one minute) at acidic $\mathrm{pH}$ when reacting only with molecular ozone at $2.8 \mathrm{mg} / \mathrm{L}$. The exception was explained by the greater selectivity of ozone towards sulfaquinoxaline compared to hydroxyl radicals [24]. At a full-scale DWTP, ozonation was the main step responsible for antibiotics degradation, with an removal rate of $65 \%$ for $1 \mathrm{mg} / \mathrm{L}$ of ozone [158]. Removal rates during ozonation may be reduced by organic matter and inorganic salts in water resources which can act as scavengers during radical reactions $[24,48,151]$. The degradation products formed and their properties depend on the oxidant (ozone or hydroxyl radical) most prevalent in the process [156]. When antibiotics react directly with ozone, degradation products appear to be biologically inactive. However, when antibiotics react with hydroxyl radicals, toxic and persistent degradation products could be generated [23,24,29,156]. For example, four degradation products were identified after sulfaquinoxaline ozonation, including three highly toxic and persistent compounds [24]. Moreover, assessing VRPs degradation pathways during ozonation is a complex task, because one VPR can lead to many by-products. For example, 27 degradation products of lomefloxacin and 9 degradation products of tetracycline have been identified after ozonation reactions [23].

\subsubsection{Adsorption on activated carbon}

Activated carbon is used to adsorb and sometimes biologically degrade (after ozonation) organic matter and micropollutants [147]. The adsorption level of VPRs on activated carbon depends on the nature, the surface area and the porosity of the adsorbent as well as on the properties of the VPR (i.e. size; $\log$ Kow and pKa) $[49,145]$. Adsorption on powder or granular activated carbon is known to remove efficiently hydrophobic pharmaceuticals from water $[28,48,49]$. VPRs are not destructed but transferred to another phase $[48,159]$ thus 
avoiding the formation of transformation products [48], except with biological activated carbon. Biological activated carbon consists in microorganisms adsorbed on the surface of the activated carbon and forming bacteria colonies [145]. Thus, VPRs may be biotransformed by contact with the bacteria and generate TPs.

Powder activated carbon at 20mg/L (pore size of 3.03nm, specific surface area of $853 \mathrm{~m}^{2} / \mathrm{g}$ ) showed high adsorption capacity $(>85 \%)$ on antibiotics belonging to six different chemical families (SAs, TCs, phenicols, quinolones, MLs, and PENs) in surface water [144]. FQs were also efficiently eliminated by powder activated carbon (diameter of $40 \mu \mathrm{m}$ ) in [160], where the removal rate of five FQs reached $80-96 \%$ after 30-40 hours. Granular activated carbon filtration efficiently removed more than $68 \%$ of the seven tetracyclines studied by [148]. Two different carbons were used in this study, a coconut-based carbon (pore volume of $0.495 \mathrm{cc} / \mathrm{g}$, specific surface area of $1230 \mathrm{~m}^{2} / \mathrm{g}$ ) and a coal-based carbon (pore volume of $0.548 \mathrm{cc} / \mathrm{g}$, specific surface area of $1110 \mathrm{~m}^{2} / \mathrm{g}$ ). Coal-based carbon was a bit more efficient, maybe due to a larger pore volume, but it was not significantly different. Biological activated carbon filtration can also be used as in [158]. For a contact time of 15 minutes, this system accounted for $23 \%, 23 \% 20 \%, 19 \%, 17 \%$ of amoxicillin, sulfamethoxazole, oxytetracycline, sulfamethazine and tetracycline removals respectively. Even if studies number on activated carbon is limited for now (few compounds tested, and few AC types), the results tend to demonstrate that activated carbon participates to the removal of VPRs in DWTPs. Nevertheless, future work will need to assess which carbon type will be more efficient for specific VPRs.

\subsubsection{Membrane filtration}

Membrane processes, such as ultrafiltration (UF) and nanofiltration (NF) are used to remove natural organic matter and disinfection by-product precursor matter such as humic acids [161]. Membranes will act as physical barriers that will reject some compounds and let some other pass through, depending on the membranes pore size and molecular weight of the substances [32]. Concerning micropollutants, results are mixed [162], even if membrane processes prove to be highly efficient in the removal of some micropollutants $([32,48,163])$. The efficiency of VPRs rejection by membrane filtration depends on VPR properties (size, molecular weight, etc.), membrane properties (molecular weight cut-off, pore size, surface charge, etc.), matrix composition (presence and nature of organic matter, ionic strength) and temperature $[32,143]$. The main rejection mechanisms for a membrane are charge and size exclusion $[143,163]$. Thus, an important aspect to consider with membrane filtration is the molecular weight cut-off, which reports the molecular weight (expressed in Dalton) of a hypothetical non-charged solute that is $90 \%$ rejected [142]. In [163], nanofiltration rejections were higher than $95 \%$ for VPRs with a molecular weight higher than $300 \mathrm{~g} / \mathrm{mol}$. As a result, TCs antibiotics with molecular weight of around $450 \mathrm{~g} / \mathrm{mol}$ were completely rejected, while sulfamethoxazole, the SAs with the lowest molecular weight $(253 \mathrm{~g} / \mathrm{mol})$, had the smallest rejection rate. Therefore, only small VPRs with a molecular weight inferior to the cutoff molecular weight of the membrane will pass through membranes processes. In a laboratoryscale test, three VPRs from different therapeutic classes (ciprofloxacin, dexamethasone and febantel) present in ultrapure water were removed (> 97\%) with the 4 different nanofiltration membranes (NF90, NF270, NF and HL) [143]. In some cases, like in presence of organic matter in the matrix, even small VPRs can be rejected by interacting with organic matter to form a macromolecular complex rejected by size exclusion. They can also undergo hydrophobic interactions with the membrane caused by organic matter, thus narrowing the pores and leading to a higher rejection [143].

Some studies mention that there is no generation of by-products with membranes [32]. Nevertheless, microbial attachment and growth on membranes [164] may lead to the 
generation on TPs by biodegradation. Depending on their sizes and molecular weights, TPs may be rejected or pass through the membrane.

\subsection{Disinfection}

Disinfection is the last step in the whole treatment process. It aims to eliminate all microorganisms before distribution of the treated water. Disinfection can be performed either with $\mathrm{O}_{3}$, chlorine-derived species or ultraviolets (UV) [153]

\subsubsection{Chlorination}

Several species with chlorine are used in DWTPs to disinfect water (free chlorine, chlorine dioxide, chloramines) but also have the potential to oxidize micropollutants. Free chlorine (i.e. hypochlorite anion and hypochlorous acid) is a non-selective oxidant widely used in DWTP at the disinfection step [21,23].

In full-scale DWTPs, different behaviours of VPRs were observed when reacting with free chlorine. In [158], only $4 \%$ of all antibiotics were removed during the disinfection step. This percentage was explained by the low concentrations of antibiotics in the influent (below 10 ng. $\mathrm{L}^{-1}$ ) and the low dosage of chlorine. It can be assumed that the low amount of chlorine will be preferentially consumed by other compounds and/or micro-organisms having higher chlorine demand than antibiotics. The quinolone flumequine, which does not have a piperazine ring, does not react at all with chlorine and the FQ enrofloxacin reacts very slowly [23]. As an explanation, organic matter may interact and form complexes with VPRs, slowing down the reaction rate with chlorine species [32]. Other VPRs are known to react heavily with chlorine such as trimethoprim, tetracyclines and FQs like ciprofloxacin or levofloxacin [23].

A major drawback of chlorination is the formation of disinfection by-products can retain the initial biological activity of the parent compounds, or even become more toxic than parent compounds [22]. Disinfection by-products of the antibiotic carbadox are believed to retain antibacterial activity as the biological active n-oxide group remains in their structures [23]. Sulfamethazine degradation by chlorine induces the formation of trihalomethanes and haloacetic acids, which are undesirable chlorination by-products, potentially carcinogenics [149]. 38 disinfection by-products were generated during the chlorination of sulfamethoxazole, sulfathiazole and sulfadimethoxine [21]. Fifteen of these disinfection byproducts may have retain antibacterial activity as their their sulfonamide functional group was preserved. Besides, 21 disinfection by-products may have acquired negative and toxic effects by the incorporation of a chlorine atom in their chemical structure [21].

Chlorine dioxide is used to replace conventional chlorine species because it does not lead to the formation of halogenated species like trihalomethanes when reacting with organic compounds $[32,150,165,166]$. Instead, chlorine dioxide induces the formation of oxygenated and hydroxylated products when reacting with TCs [23]. In addition, chlorine dioxide is more selective than free chlorine, and does not react with aromatic, hydrocarbons, carbohydrates, primary and secondary amines, aldehydes, and ketones or piperazine ring. Consequently, the antibacterial activity of FQs remains after the disinfection step with chlorine dioxide. Chlorine dioxide reacts with phenols and tertiary amine groups or piperazine rings $[23,32,166]$. This is supported by the fact that [166] noticed a chlorination of the piperazine ring of enrofloxacin and ciprofloxacin.

Chloramine can also be used for disinfection in DWTPs. However, there is a concern that their reaction with micropollutants like VPRs may lead to the formation of carcinogenic N- 
nitrosodimethylamine (NDMA) [28]. Indeed, some VPRs with diethylamine groups are very reactive with chloramine. Spiramycin and minocycline were transformed respectively at 3.4 and $4.9 \%$ into NDMA in [28]. The carcinogenic effect of the resulting NDMA solutions has not been assessed in the study. However, as NMDA is classified as a carcinogenic compound at low concentration levels (ng. $\left.\mathrm{L}^{-1}\right)$ [28] it can be assumed than it can be harmful to human health.

\subsubsection{Ultraviolets $(U V)$}

UV $(254 \mathrm{~nm})$ is used in DWTPs as a disinfectant, but it can also contribute to the reduction of water contamination by some chemical families of VPRs. Efficiency of VPRs removal by UV oxidation depends on the ability of the VPR to absorb at $254 \mathrm{~nm}$, the UV fluence (i.e. UV dose, expressed in $\mathrm{mJ} / \mathrm{m}^{2}$ ) and on the irradiation time [167,168]. For twelve SAs (sulfaguanidine, sulfadiazine, sulfamerazine, sulfamethazine, sulfathiazole, sulfamethizole, sulfamethoxazole, sulfonamide, sulfisoxazole, sulfachloropyridazine, sulfamethoxydiazine, sulfadimethoxine) direct UV photolysis at $254 \mathrm{~nm}$ was very efficient, with removal rates between $95 \%$ and $100 \%$ after 30 minutes of irradiation. It was noticed that SAs with a fivemembered heterocycle undergo a higher removal rate than sulfonamides with a six-membered heterocycle [169]. Four ionophores (monensin, salinomycin, nigericin and narasin) were completely degraded in 300 seconds. Faster degradation was observed for salinomycin and narasin than monensin. This difference was attributed to the extra double bonds of narasin and salinomycin [168]. UV photolysis can generate transformation products with equal or higher antibacterial activity. For example, the FQ enrofloxacin can be degraded into ciprofloxacin, which is also used as a pharmaceutical [167].

\subsection{Overall removal efficiencies}

In [158] the behavior of six veterinary antibiotics was studied in an industrial-scale DWTP including coagulation, sedimentation, sand filtration and chlorination processes, combined with an advanced treatment process composed of ozonation and biological activated carbon. $91 \%$ of total antibiotics were removed during the whole process $(85 \%$ for amoxicillin; $86 \%$ for oxytetracycline; $92 \%$ for tetracycline; and complete removal for sulfamethoxazole, sulfamethazine, and erythromycin) [158].

In 2011, [135] studied a DWTP composed of dioxychlorination, clarification and a separation of water into two parallel treatment lines. The first treatment line was a conventional one (ozonation and granular activated carbon filtration) and the second an advanced one (ultrafiltration, ultraviolets and reverse osmosis). The two different treatment lines (conventional one and advanced one) were then blended and the water was chlorinated and distributed. Reverse osmosis is not usually used for drinking water treatment, but in [135] the raw water quality was altered by salt mine exploitations, so reverse osmosis was applied for desalination.

Six veterinary antibiotics (lincomycin, sulfamethoxazole, sulfadimethoxine, sulfamethazine, trimethoprim and tylosin) were studied and efficiently eliminated with removal percentages > 99\%. Lincomycin, sulfamethoxazole and trimethoprim were totally removed with both applied treatments (conventional and advanced). The conventional treatment was more effective to remove sulfadimethoxine and sulfamethazine than the advanced treatment. On the other hand, tylosin was eliminated at $99 \%$ with the advanced treatment and at $94 \%$ with the conventional treatment [135]. 
Other studies reported complete removal of the studied VPRs with conventional treatments for the following compounds: lincomycin [147,170], sulfamethazine [170], sulfadimethoxine [170], and sulfathiazole [170], tiamulin [147], flunixin [155]. Influent concentration levels ranged from 4 ng. $\mathrm{L}^{-1}$ to $50 \mathrm{ng} . \mathrm{L}^{-1}[147,155,170]$.

\section{CONCLUSION AND WAY FORWARD}

VPRs have been widely quantified in natural waters (either surface water or groundwater) between 2007 and 2017, from $1 \mathrm{ng} . \mathrm{L}^{-1}$ to $255 \mu \mathrm{g} . \mathrm{L}^{-1}$. This demonstrates that natural waters contamination by VPRs is still an actual issue that must be evaluated and managed. Plenty of parameters are involved in the dynamics (occurrence, mobility, persistence) of VPRs in natural water, depending on spatial aspects and temporal aspects. An emphasis is made on sales and uses of VPRs which are major factors impacting their occurrence. The update provided in this review on VPRs sales worldwide (regarding the available information) shows that sales tend to decrease in most countries with the exception of the USA and in New Zealand. TCs are the most sold veterinary antibiotics worldwide, followed by PENs, MLs and SAs. Compared to ten years ago, more countries sales data are available in the public domain which is an improvement. Indeed, sales information enables a better targeting of the compounds to be sought in the environment of specific countries. Nevertheless, sales amounts of probably important VPRs consumer countries such as China, India or Canada are not yet available. Considering fate of VPRs in natural waters, studies published over the past few years have provided knowledge on the degradation mechanisms in natural waters. VPRs can be degraded or transformed by biodegradation, hydrolysis or photolysis. Photodegradation appears to be the major degradation pathway in SW.

Only few studies were published on VPRs occurrence in tap water (11 studies), as shown in section 3. Nevertheless, veterinary antibiotics have been detected from traces to 100ng. $\mathrm{L}^{-1}$. Those concentration levels are unlikely to cause acute toxicity effects on human health[171]. However there is a concern as VPRs are added to the cocktails of micropollutants already present in drinking water, such as human drug residues, pesticides, biocides, flame retardants, metals [172,173]. It is therefore important to understand fate of VPRs in DWTPs. Overall removals of VPRs in DWTPs generally exceed 90\% and advanced treatment processes (oxidation processes, adsorption on activated carbon, membrane filtration) greatly contribute to these removals. However, studies in VPRs fate performed on full-scale DWTPs are scarce (6 studies).

Figure 4 is focusing on studies on fate of VPRs in natural waters and fate of VPRs in DWTPs (however, studies on VPRs occurrence in natural and tap water are not considered). Among the 38 studies dealing with VPRs fate in natural waters, only $18 \%$ were conducted under environmentally relevant conditions. Conditions considered as environmentally relevant were the following: VPRs concentrations below $100 \mu \mathrm{g} . \mathrm{L}^{-1}$; natural sunlight; natural water. Conditions considered as environmentally irrelevant were the following: VPR concentrations higher than $100 \mu \mathrm{g} . \mathrm{L}^{-1}$, artificial sunlight, deionized water.

\section{[Figure 4]}

Among the 28 selected papers on the fate of VPRs in DWTP, only $21 \%$ were performed under relevant full-scale DWTP conditions (Figure 4). Additional parameters such as concentration of the reactive used in DWTP (oxidant for example) and contact time were considered. This suggests that results of fate studies in DWTP should be considered with caution as the removal rates may be different in full-scale DWTP conditions. Although the issue of experimental conditions and experimental concentrations levels has long been emphasized in 
order to accurately reproduce environmental phenomena, it seems that there are still improvements to be made.

Also, oxidation processes can result in the formation of oxidation by-products that may be more toxic than the parent compound. Currently the formation pathway, the chemical structure and the potential impacts of these transformation products on human health are largely unknown and need to be investigated. To finish, many VRPs have not been investigated yet. There is a scientific gap on the occurrence and fate of antiparatic drugs in natural waters and tap water (only 11 studies considered versus 105 studies on antibiotics).

\section{ACKNOWLEDGMENTS}

This work was supported by La Région Bretagne (COH15002), L'Agence Française de la Biodiversité (Project no. 224), EHESP (2015/539/DRH/EHESP), ARS and DREAL Bretagne (56/2016/277).

Declarations of interest: none. 


\section{REFERENCES}

[1] T.P. Van Boeckel, C. Brower, M. Gilbert, B.T. Grenfell, S.A. Levin, T.P. Robinson, A. Teillant, R. Laxminarayan, Global trends in antimicrobial use in food animals, Proc. Natl. Acad. Sci. 112 (2015) 5649-5654. doi:10.1073/pnas.1503141112.

[2] S. Bartelt-Hunt, D.D. Snow, T. Damon-Powell, D. Miesbach, Occurrence of steroid hormones and antibiotics in shallow groundwater impacted by livestock waste control facilities, J. Contam. Hydrol. 123 (2011) 94-103. doi:10.1016/j.jconhyd.2010.12.010.

[3] S. Obimakinde, O. Fatoki, B. Opeolu, O. Olatunji, Veterinary pharmaceuticals in aqueous systems and associated effects: an update, Environ. Sci. Pollut. Res. 24 (2017) 3274-3297. doi:10.1007/s11356-016-7757-z.

[4] R.R. Kumar, J.T. Lee, J.Y. Cho, Fate, occurrence, and toxicity of veterinary antibiotics in environment, J. Korean Soc. Appl. Biol. Chem. 55 (2012) 701-709. doi:10.1007/s13765-0122220-4.

[5] A. Van Epps, L. Blaney, Antibiotic Residues in Animal Waste: Occurrence and Degradation in Conventional Agricultural Waste Management Practices, Curr. Pollut. Rep. 2 (2016) 135-155. doi:10.1007/s40726-016-0037-1.

[6] L. Du, W. Liu, Occurrence, fate, and ecotoxicity of antibiotics in agro-ecosystems. A review, Agron. Sustain. Dev. 32 (2012) 309-327. doi:10.1007/s13593-011-0062-9.

[7] K.-R. Kim, G. Owens, S.-I. Kwon, K.-H. So, D.-B. Lee, Y.S. Ok, Occurrence and Environmental Fate of Veterinary Antibiotics in the Terrestrial Environment, Water. Air. Soil Pollut. 214 (2011) 163174. doi:10.1007/s11270-010-0412-2.

[8] R.P. Tasho, J.Y. Cho, Veterinary antibiotics in animal waste, its distribution in soil and uptake by plants: A review, Sci. Total Environ. 563-564 (2016) 366-376. doi:10.1016/j.scitotenv.2016.04.140.

[9] S.A. Kools, A. Boxall, J.F. Moltmann, G. Bryning, J. Koschorreck, T. Knacker, A ranking of European veterinary medicines based on environmental risks, Integr. Environ. Assess. Manag. 4 (2008) 399-408.

[10] A.B.A. Boxall, Veterinary Medicines and the Environment, in: F. Cunningham, J. Elliott, P. Lees (Eds.), Comp. Vet. Pharmacol., Springer Berlin Heidelberg, Berlin, Heidelberg, 2010: pp. 291314. doi:10.1007/978-3-642-10324-7_12.

[11] D.S. Jeon, T.-K. Oh, M. Park, D.S. Lee, Y.J. Lim, J.S. Shin, S.G. Song, S.C. Kim, Y. Shinogi, D.Y. Chung, Reactions and Behavior Relevant to Chemical and Physical Properties of Various Veterinary Antibiotics in Soil, J. Fac. Agric. Kyushu Univ. 59 (2014) 391-397.

[12] H. Bártíková, R. Podlipná, L. Skálová, Veterinary drugs in the environment and their toxicity to plants, Chemosphere. 144 (2016) 2290-2301. doi:10.1016/j.chemosphere.2015.10.137.

[13] A. Iglesias, C. Nebot, J.M. Miranda, B.I. Vázquez, A. Cepeda, Detection and quantitative analysis of 21 veterinary drugs in river water using high-pressure liquid chromatography coupled to tandem mass spectrometry, Environ. Sci. Pollut. Res. 19 (2012) 3235-3249. doi:10.1007/s11356-012-0830-3.

[14] A. Iglesias, C. Nebot, B.I. Vázquez, J.M. Miranda, C.M.F. Abuín, A. Cepeda, Detection of veterinary drug residues in surface waters collected nearby farming areas in Galicia, North of Spain, Environ. Sci. Pollut. Res. 21 (2014) 2367-2377. doi:10.1007/s11356-013-2142-7.

[15] W.-Y. Xie, Q. Shen, F.J. Zhao, Antibiotics and antibiotic resistance from animal manures to soil: a review: Antibiotics and antibiotic resistance, Eur. J. Soil Sci. 69 (2018) 181-195. doi:10.1111/ejss.12494.

[16] N. Kemper, Veterinary antibiotics in the aquatic and terrestrial environment, Ecol. Indic. 8 (2008) 1-13. doi:http://dx.doi.org/10.1016/j.ecolind.2007.06.002. 
[17] M. Sturini, A. Speltini, F. Maraschi, A. Profumo, L. Pretali, E. Fasani, A. Albini, Photochemical degradation of marbofloxacin and enrofloxacin in natural waters, Environ. Sci. Technol. 44 (2010) 4564-4569.

[18] J.J. Guerard, Y.-P. Chin, H. Mash, C.M. Hadad, Photochemical fate of sulfadimethoxine in aquaculture waters, Environ. Sci. Technol. 43 (2009) 8587-8592.

[19] P. Sun, S.G. Pavlostathis, C.-H. Huang, Photodegradation of Veterinary lonophore Antibiotics under UV and Solar Irradiation, Environ. Sci. Technol. 48 (2014) 13188-13196. doi:10.1021/es5034525.

[20] C.P. Youngquist, S.M. Mitchell, C.G. Cogger, Fate of Antibiotics and Antibiotic Resistance during Digestion and Composting: A Review, J. Environ. Qual. 45 (2016) 537. doi:10.2134/jeq2015.05.0256.

[21] M. Wang, D.E. Helbling, A non-target approach to identify disinfection byproducts of structurally similar sulfonamide antibiotics, Water Res. 102 (2016) 241-251. doi:10.1016/j.watres.2016.06.042.

[22] H. Dong, Z. Qiang, J. Hu, J. Qu, Degradation of chloramphenicol by UV/chlorine treatment: Kinetics, mechanism and enhanced formation of halonitromethanes, Water Res. 121 (2017) 178-185. doi:10.1016/j.watres.2017.05.030.

[23] C. Postigo, S.D. Richardson, Transformation of pharmaceuticals during oxidation/disinfection processes in drinking water treatment, J. Hazard. Mater. 279 (2014) 461-475. doi:10.1016/j.jhazmat.2014.07.029.

[24] V.R. Urbano, M.G. Maniero, M. Pérez-Moya, J.R. Guimarães, Influence of pH and ozone dose on sulfaquinoxaline ozonation, J. Environ. Manage. 195 (2017) 224-231. doi:10.1016/j.jenvman.2016.08.019.

[25] P.M. Peltzer, R.C. Lajmanovich, A.M. Attademo, C.M. Junges, C.M. Teglia, C. Martinuzzi, L. Curi, M.J. Culzoni, H.C. Goicoechea, Ecotoxicity of veterinary enrofloxacin and ciprofloxacin antibiotics on anuran amphibian larvae, Environ. Toxicol. Pharmacol. 51 (2017) 114-123. doi:10.1016/j.etap.2017.01.021.

[26] S. Jiao, S. Zheng, D. Yin, L. Wang, L. Chen, Aqueous photolysis of tetracycline and toxicity of photolytic products to luminescent bacteria, Chemosphere. 73 (2008) 377-382. doi:10.1016/j.chemosphere.2008.05.042.

[27] K.H. Wammer, A.R. Korte, R.A. Lundeen, J.E. Sundberg, K. McNeill, W.A. Arnold, Direct photochemistry of three fluoroquinolone antibacterials: Norfloxacin, ofloxacin, and enrofloxacin, Water Res. 47 (2013) 439-448. doi:10.1016/j.watres.2012.10.025.

[28] S.L. Leavey-Roback, S.W. Krasner, I. (Mel) H. Suffet, Veterinary antibiotics used in animal agriculture as NDMA precursors, Chemosphere. 164 (2016) 330-338. doi:10.1016/j.chemosphere.2016.08.070.

[29] M. Sánchez-Polo, J. Rivera-Utrilla, G. Prados-Joya, M.A. Ferro-García, I. Bautista-Toledo, Removal of pharmaceutical compounds, nitroimidazoles, from waters by using the ozone/carbon system, Water Res. 42 (2008) 4163-4171. doi:10.1016/j.watres.2008.05.034.

[30] D.S. Aga, M. Lenczewski, D. Snow, J. Muurinen, J.B. Sallach, J.S. Wallace, Challenges in the Measurement of Antibiotics and in Evaluating Their Impacts in Agroecosystems: A Critical Review, J. Environ. Qual. 45 (2016) 407. doi:10.2134/jeq2015.07.0393.

[31] A.B. Boxall, D.W. Kolpin, B. Halling-Sørensen, J. Tolls, Are veterinary medicines causing environmental risks?, J Env. Sci Technol. 37 (2003). doi:10.1021/es032519b.

[32] V. Homem, L. Santos, Degradation and removal methods of antibiotics from aqueous matricesa review, J Env. Manage. 92 (2011). doi:10.1016/j.jenvman.2011.05.023.

[33] F. Kaczala, S. E Blum, The Occurrence of Veterinary Pharmaceuticals in the Environment: $A$ Review, Curr. Anal. Chem. 12 (2016) 169-182.

[34] S.J. Khan, D.J. Roser, C.M. Davies, G.M. Peters, R.M. Stuetz, R. Tucker, N.J. Ashbolt, Chemical contaminants in feedlot wastes: Concentrations, effects and attenuation, Environ. Int. 34 (2008) 839-859. doi:10.1016/j.envint.2007.10.007. 
[35] K. Kümmerer, Antibiotics in the aquatic environment - A review - Part I, Chemosphere. 75 (2009) 417-434. doi:10.1016/j.chemosphere.2008.11.086.

[36] K. Kümmerer, Antibiotics in the aquatic environment - A review - Part II, Chemosphere. 75 (2009) 435-441. doi:10.1016/j.chemosphere.2008.12.006.

[37] J.-P. Lumaret, F. Errouissi, K. Floate, J. Rombke, K. Wardhaugh, A review on the toxicity and non-target effects of macrocyclic lactones in terrestrial and aquatic environments, Curr. Pharm. Biotechnol. 13 (2012) 1004-1060.

[38] A.K. Sarmah, M.T. Meyer, A.B.A. Boxall, A global perspective on the use, sales, exposure pathways, occurrence, fate and effects of veterinary antibiotics (VAs) in the environment, Chemosphere. 65 (2006) 725-759. doi:10.1016/j.chemosphere.2006.03.026.

[39] M. Slana, M.S. Dolenc, Environmental Risk Assessment of antimicrobials applied in veterinary medicine-A field study and laboratory approach, Environ. Toxicol. Pharmacol. 35 (2013) 131141. doi:10.1016/j.etap.2012.11.017.

[40] D.D. Snow, S.L. Bartelt-Hunt, D.L. Brown, J. Sangster, D.A. Cassada, Detection, Occurrence and Fate of Pharmaceuticals and Steroid Hormones in Agricultural Environments, Water Environ. Res. 82 (2010) 869-882. doi:10.2175/106143010X12756668800618.

[41] S. Thiele-Bruhn, Pharmaceutical antibiotic compounds in soils - a review, J. Plant Nutr. Soil Sci. 166 (2003) 145-167. doi:10.1002/jpln.200390023.

[42] J. Tolls, Sorption of veterinary pharmaceuticals in soils: a review, Env. Sci Technol. 35 (2001). doi:10.1021/es0003021.

[43] P.J. Van den Brink, J.V. Tarazona, K.R. Solomon, T. Knacker, N.W. Van den Brink, T. Brock, J.P. Hoogland, The use of terrestrial and aquatic microcosms and mesocosms for the ecological risk assessment of veterinary medicinal products, Environ. Toxicol. Chem. 24 (2005) 820-829.

[44] S.R. Wegst-Uhrich, D.A. Navarro, L. Zimmerman, D.S. Aga, Assessing antibiotic sorption in soil: a literature review and new case studies on sulfonamides and macrolides, Chem. Cent. J. 8 (2014) 5.

[45] Y. Li, B. Liu, X. Zhang, J. Wang, S. Gao, The distribution of veterinary antibiotics in the river system in a livestock-producing region and interactions between different phases, Environ. Sci. Pollut. Res. 23 (2016) 16542-16551. doi:10.1007/s11356-016-6677-2.

[46] L. Yao, Y. Wang, L. Tong, Y. Li, Y. Deng, W. Guo, Y. Gan, Seasonal variation of antibiotics concentration in the aquatic environment: a case study at Jianghan Plain, central China, Sci. Total Environ. 527-528 (2015) 56-64. doi:10.1016/j.scitotenv.2015.04.091.

[47] L. Yao, Y. Wang, L. Tong, Y. Deng, Y. Li, Y. Gan, W. Guo, C. Dong, Y. Duan, K. Zhao, Occurrence and risk assessment of antibiotics in surface water and groundwater from different depths of aquifers: A case study at Jianghan Plain, central China, Ecotoxicol. Environ. Saf. 135 (2017) 236242. doi:10.1016/j.ecoenv.2016.10.006.

[48] Y. Yang, Y.S. Ok, K.-H. Kim, E.E. Kwon, Y.F. Tsang, Occurrences and removal of pharmaceuticals and personal care products (PPCPs) in drinking water and water/sewage treatment plants: A review, Sci. Total Environ. 596-597 (2017) 303-320. doi:10.1016/j.scitotenv.2017.04.102.

[49] M.J. Ahmed, Adsorption of quinolone, tetracycline, and penicillin antibiotics from aqueous solution using activated carbons: Review, Environ. Toxicol. Pharmacol. 50 (2017) 1-10. doi:10.1016/j.etap.2017.01.004.

[50] J. Olsen, E. Björklund, K.A. Krogh, M. Hansen, Development of an analytical methodology for the determination of the antiparasitic drug toltrazuril and its two metabolites in surface water, soil and animal manure, Anal. Chim. Acta. 755 (2012) 69-76. doi:10.1016/j.aca.2012.10.015.

[51] T.S. Thompson, D.K. Noot, F. Forrest, J.P. van den Heever, J. Kendall, J. Keenliside, Large volume injection for the direct analysis of ionophores and avermectins in surface water by liquid chromatography-electrospray ionization tandem mass spectrometry, Anal. Chim. Acta. 633 (2009) 127-135. doi:10.1016/j.aca.2008.11.024.

[52] M.J. Bernot, L. Smith, J. Frey, Human and veterinary pharmaceutical abundance and transport in a rural central Indiana stream influenced by confined animal feeding operations (CAFOs), Sci. Total Environ. 445-446 (2013) 219-230. doi:10.1016/j.scitotenv.2012.12.039. 
[53] L.-J. Zhou, Q.L. Wu, B.-B. Zhang, Y. Zhao, B.-Y. Zhao, Occurrence, spatiotemporal distribution, mass balance and ecological risks of antibiotics in the subtropical shallow Lake Taihu, China, Environ. Sci. Process. Impacts. (2016). doi:10.1039/C6EM00062B.

[54] L. Tong, S. Huang, Y. Wang, H. Liu, M. Li, Occurrence of antibiotics in the aquatic environment of Jianghan Plain, central China, Sci. Total Environ. 497-498 (2014) 180-187. doi:10.1016/j.scitotenv.2014.07.068.

[55] L. Tong, P. Li, Y. Wang, K. Zhu, Analysis of veterinary antibiotic residues in swine wastewater and environmental water samples using optimized SPE-LC/MS/MS, Chemosphere. 74 (2009) 1090-1097. doi:10.1016/j.chemosphere.2008.10.051.

[56] S. Managaki, A. Murata, H. Takada, B.C. Tuyen, N.H. Chiem, Distribution of Macrolides, Sulfonamides, and Trimethoprim in Tropical Waters: Ubiquitous Occurrence of Veterinary Antibiotics in the Mekong Delta, Environ. Sci. Technol. 41 (2007) 8004-8010. doi:10.1021/es0709021.

[57] Y. Luo, L. Xu, M. Rysz, Y. Wang, H. Zhang, P.J.J. Alvarez, Occurrence and Transport of Tetracycline, Sulfonamide, Quinolone, and Macrolide Antibiotics in the Haihe River Basin, China, Environ. Sci. Technol. 45 (2011) 1827-1833. doi:10.1021/es104009s.

[58] J. Jiang, L. Ye, Y. Chen, Contamination of Surface Water with Veterinary Antibiotics in Tiaoxi River Basin, East China, Asian J. Chem. 26 (2014) 8453-8459. doi:10.14233/ajchem.2014.17941.

[59] V. Burke, D. Richter, J. Greskowiak, A. Mehrtens, L. Schulz, G. Massmann, Occurrence of Antibiotics in Surface and Groundwater of a Drinking Water Catchment Area in Germany, Water Environ. Res. 88 (2016) 652-659. doi:10.2175/106143016X14609975746604.

[60] A. Selvam, K. Kwok, Y. Chen, A. Cheung, K.S.Y. Leung, J.W.C. Wong, Influence of livestock activities on residue antibiotic levels of rivers in Hong Kong, Environ. Sci. Pollut. Res. 24 (2017) 9058-9066. doi:10.1007/s11356-016-6338-5.

[61] Y.S. Ok, S.-C. Kim, K.-R. Kim, S.S. Lee, D.H. Moon, K.J. Lim, J.-K. Sung, S.-O. Hur, J.E. Yang, Monitoring of selected veterinary antibiotics in environmental compartments near a composting facility in Gangwon Province, Korea, Environ. Monit. Assess. 174 (2011) 693-701.

[62] R. Wei, F. Ge, S. Huang, M. Chen, R. Wang, Occurrence of veterinary antibiotics in animal wastewater and surface water around farms in Jiangsu Province, China, Chemosphere. 82 (2011) 1408-1414. doi:10.1016/j.chemosphere.2010.11.067.

[63] Y. Kim, K.-B. Lee, K. Choi, Effect of runoff discharge on the environmental levels of 13 veterinary antibiotics: A case study of Han River and Kyungahn Stream, South Korea, Mar. Pollut. Bull. 107 (2016) 347-354. doi:10.1016/j.marpolbul.2016.03.011.

[64] X. Zhang, Y. Li, B. Liu, J. Wang, C. Feng, M. Gao, L. Wang, Prevalence of Veterinary Antibiotics and Antibiotic-Resistant Escherichia coli in the Surface Water of a Livestock Production Region in Northern China, PLoS ONE. 9 (2014) e111026. doi:10.1371/journal.pone.0111026.

[65] Y. Matsui, T. Ozu, T. Inoue, T. Matsushita, Occurrence of a veterinary antibiotic in streams in a small catchment area with livestock farms, Desalination. 226 (2008) 215-221. doi:10.1016/j.desal.2007.01.243.

[66] J.-Y. Pailler, A. Krein, L. Pfister, L. Hoffmann, C. Guignard, Solid phase extraction coupled to liquid chromatography-tandem mass spectrometry analysis of sulfonamides, tetracyclines, analgesics and hormones in surface water and wastewater in Luxembourg, Sci. Total Environ. 407 (2009) 4736-4743. doi:10.1016/j.scitotenv.2009.04.042.

[67] M.S. Díaz-Cruz, M.J. García-Galán, D. Barceló, Highly sensitive simultaneous determination of sulfonamide antibiotics and one metabolite in environmental waters by liquid chromatography-quadrupole linear ion trap-mass spectrometry, J. Chromatogr. A. 1193 (2008) 50-59. doi:10.1016/j.chroma.2008.03.029.

[68] A. Murata, H. Takada, K. Mutoh, H. Hosoda, A. Harada, N. Nakada, Nationwide monitoring of selected antibiotics: Distribution and sources of sulfonamides, trimethoprim, and macrolides in Japanese rivers, Sci. Total Environ. 409 (2011) 5305-5312. doi:10.1016/j.scitotenv.2011.09.014. 
[69] A. Pena, D. Chmielova, C.M. Lino, P. Solich, Determination of fluoroquinolone antibiotics in surface waters from Mondego River by high performance liquid chromatography using a monolithic column, J. Sep. Sci. 30 (2007) 2924-2928. doi:10.1002/jssc.200700363.

[70] S. Kurwadkar, V. Sicking, B. Lambert, A. McFarland, F. Mitchell, Preliminary studies on occurrence of monensin antibiotic in Bosque River Watershed, J. Environ. Sci. 25 (2013) 268273. doi:10.1016/S1001-0742(12)60041-2.

[71] P. Sun, D. Barmaz, M.L. Cabrera, S.G. Pavlostathis, C.-H. Huang, Detection and quantification of ionophore antibiotics in runoff, soil and poultry litter, J. Chromatogr. A. 1312 (2013) 10-17. doi:http://dx.doi.org/10.1016/j.chroma.2013.08.044.

[72] M. Zrnčić, M. Gros, S. Babić, M. Kaštelan-Macan, D. Barcelo, M. Petrović, Analysis of anthelmintics in surface water by ultra high performance liquid chromatography coupled to quadrupole linear ion trap tandem mass spectrometry, Chemosphere. 99 (2014) 224-232. doi:10.1016/j.chemosphere.2013.10.091.

[73] M. Wagil, J. Maszkowska, A. Białk-Bielińska, P. Stepnowski, J. Kumirska, A comprehensive approach to the determination of two benzimidazoles in environmental samples, Chemosphere. 119 (2015) S35-S41. doi:10.1016/j.chemosphere.2014.04.106.

[74] M. Wagil, A. Białk-Bielińska, J. Maszkowska, P. Stepnowski, J. Kumirska, Critical points in the evaluation of analytical methods based on liquid chromatography separation for the determination of doramectin in different environmental samples, Chemosphere. 119 (2015) S9-S15. doi:10.1016/j.chemosphere.2014.03.137.

[75] M. Wagil, J. Maszkowska, A. Białk-Bielińska, M. Caban, P. Stepnowski, J. Kumirska, Determination of metronidazole residues in water, sediment and fish tissue samples, Chemosphere. (2014). doi:http://dx.doi.org/10.1016/j.chemosphere.2013.12.061.

[76] F.-Y. Hu, L.-M. He, J.-W. Yang, K. Bian, Z.-N. Wang, H.-C. Yang, Y.-H. Liu, Determination of 26 veterinary antibiotics residues in water matrices by lyophilization in combination with LCMS/MS, J. Chromatogr. B. 949-950 (2014) 79-86. doi:10.1016/j.jchromb.2014.01.008.

[77] N. Watanabe, B.A. Bergamaschi, K.A. Loftin, M.T. Meyer, T. Harter, Use and Environmental Occurrence of Antibiotics in Freestall Dairy Farms with Manured Forage Fields, Environ. Sci. Technol. 44 (2010) 6591-6600. doi:10.1021/es100834s.

[78] X. Hu, Q. Zhou, Y. Luo, Occurrence and source analysis of typical veterinary antibiotics in manure, soil, vegetables and groundwater from organic vegetable bases, northern China, Environ. Pollut. 158 (2010) 2992-2998. doi:10.1016/j.envpol.2010.05.023.

[79] M.J. García-Galán, T. Garrido, J. Fraile, A. Ginebreda, M.S. Díaz-Cruz, D. Barceló, Simultaneous occurrence of nitrates and sulfonamide antibiotics in two ground water bodies of Catalonia (Spain), J. Hydrol. 383 (2010) 93-101. doi:10.1016/j.jhydrol.2009.06.042.

[80] F. Balzer, S. Zuhlke, S. Hannappel, Antibiotics in groundwater under locations with high livestock density in Germany, Water Sci. Technol. Water Supply. 16 (2016) 1361-1369. doi:10.2166/ws.2016.050.

[81] N. Watanabe, T.H. Harter, B.A. Bergamaschi, Environmental Occurrence and Shallow Ground Water Detection of the Antibiotic Monensin from Dairy Farms, J. Environ. Qual. 37 (2008) S-78. doi:10.2134/jeq2007.0371.

[82] ANSES (French Agency for Environmental and Occupational Health Safety), Campagne nationale d'occurrence des résidus de medicaments dans les eaux destinées à la consummation humaine, (2011). https://www.anses.fr/fr/system/files/LABO-Ra-EtudeMedicamentsEaux.pdf.

[83] Y.M. Awad, S.-C. Kim, S.A.M. Abd El-Azeem, K.-H. Kim, K.-R. Kim, K. Kim, C. Jeon, S.S. Lee, Y.S. Ok, Veterinary antibiotics contamination in water, sediment, and soil near a swine manure composting facility, Environ. Earth Sci. 71 (2014) 1433-1440. doi:10.1007/s12665-013-2548-z.

[84] A. Jaffrézic, E. Jardé, A. Soulier, L. Carrera, E. Marengue, A. Cailleau, B. Le Bot, Veterinary pharmaceutical contamination in mixed land use watersheds: from agricultural headwater to water monitoring watershed, Sci. Total Environ. 609 (2017) 992-1000. doi:10.1016/j.scitotenv.2017.07.206. 
[85] D.J. Lapworth, N. Baran, M.E. Stuart, R.S. Ward, Emerging organic contaminants in groundwater: A review of sources, fate and occurrence, Environ. Pollut. 163 (2012) 287-303. doi:10.1016/j.envpol.2011.12.034.

[86] D.D. Snow, S.L. Bartelt-Hunt, S.E. Saunders, S.L. Devivo, D.A. Cassada, Detection, Occurrence and Fate of Emerging Contaminants in Agricultural Environments, Water Environ. Res. 80 (2008) 868-2092. doi:10.2175/106143008X328518.

[87] Food and Drug Administration (FDA), Summary report on antimicrobials sold or distributed for use in food-producing animal, (2017).

[88] Y. Hu, H. Cheng, Health risk from veterinary antimicrobial use in China's food animal production and its reduction, Environ. Pollut. 219 (2016) 993-997. doi:10.1016/j.envpol.2016.04.099.

[89] European Medicines Agency (EMA), European Surveillance of Veterinary Antimicrobial Consumption. Sales of veterinary antimicrobial agents in 30 European countries in 2015 (EMA/184855/2017), (2017).

[90] European Commission (EC), Regulation (EC) No. 1831/2003 of the European Parliament and of the Council of 22 September 2003 on Additives for Use in Animal Nutrition., (2003).

[91] D. Méheust, A. Chevance, G. Moulin, Suivi des ventes de médicaments vétérinaires contenant des antibiotiques en France en 2016. Rapport annuel, Anses, 2017.

[92] Veterinary Medicines Directorate, UK Veterinary Antibiotic Resistance and Sales Surveillance Report, 2016, (2017).

[93] P. Collignon, A. Voss, China, what antibiotics and what volumes are used in food production animals?, Antimicrob. Resist. Infect. Control. 4 (2015). doi:10.1186/s13756-015-0056-5.

[94] W.Y. Mo, Z. Chen, H.M. Leung, A.O.W. Leung, Application of veterinary antibiotics in China's aquaculture industry and their potential human health risks, Environ. Sci. Pollut. Res. 24 (2017) 8978-8989. doi:10.1007/s11356-015-5607-z.

[95] Ministry of Agriculture, Food and Rural Affairs (MAFRA), Monitoring and characterization of antimicrobial resistance of bacteria from livestock products, (2015).

[96] Ministry of Agriculture, Forestry \& Fisheries (MAFF), Sales Amounts and Sales Volumes (Active Substance) of Antibiotics, Synthetic Antibacterials, Antihelmintics and Antiprotozoals, (2015).

[97] Ministry of Agriculture, Forestry \& Fisheries (MAFF), Sales Amounts and Sales Volumes (Active Substance) of Antibiotics, Synthetic Antibacterials, Antihelmintics and Antiprotozoals, (2007).

[98] Australian Pesticides and Veterinary Medicines Authority (APVMA), Quantity of antimicrobial products sold for veterinary use in Australia 2005-2010, (2014).

[99] Ministry for Primary Industries, 2011-2014 Antibiotic Sales Analysis, (2016).

[100] D. Dong, L. Zhang, S. Liu, Z. Guo, X. Hua, Antibiotics in water and sediments from Liao River in Jilin Province, China: occurrence, distribution, and risk assessment, Environ. Earth Sci. 75 (2016). doi:10.1007/s12665-016-6008-4.

[101] D. Cheng, X. Liu, S. Zhao, B. Cui, J. Bai, Z. Li, Influence of the natural colloids on the multi-phase distributions of antibiotics in the surface water from the largest lake in North China, Sci. Total Environ. 578 (2017) 649-659. doi:10.1016/j.scitotenv.2016.11.012.

[102] K. Schauss, A. Focks, H. Heuer, A. Kotzerke, H. Schmitt, S. Thiele-Bruhn, K. Smalla, B.-M. Wilke, M. Matthies, W. Amelung, J. Klasmeier, M. Schloter, Analysis, fate and effects of the antibiotic sulfadiazine in soil ecosystems, TrAC Trends Anal. Chem. 28 (2009) 612-618. doi:10.1016/j.trac.2009.02.009.

[103] S. Jechalke, H. Heuer, J. Siemens, W. Amelung, K. Smalla, Fate and effects of veterinary antibiotics in soil, Trends Microbiol. 22 (2014) 536-545. doi:10.1016/j.tim.2014.05.005.

[104] Q. Li, J. Gao, Q. Zhang, L. Liang, H. Tao, Distribution and Risk Assessment of Antibiotics in a Typical River in North China Plain, Bull. Environ. Contam. Toxicol. 98 (2017) 478-483. doi:10.1007/s00128-016-2023-0.

[105] J.-F. Yang, G.-G. Ying, J.-L. Zhao, R. Tao, H.-C. Su, F. Chen, Simultaneous determination of four classes of antibiotics in sediments of the Pearl Rivers using RRLC-MS/MS, Sci. Total Environ. 408 (2010) 3424-3432. doi:10.1016/j.scitotenv.2010.03.049. 
[106] S.-C. Kim, K. Carlson, Temporal and spatial trends in the occurrence of human and veterinary antibiotics in aqueous and river sediment matrices, Environ. Sci. Technol. 41 (2007) 50-57.

[107] X. Liang, B. Chen, X. Nie, Z. Shi, X. Huang, X. Li, The distribution and partitioning of common antibiotics in water and sediment of the Pearl River Estuary, South China, Chemosphere. 92 (2013) 1410-1416. doi:10.1016/j.chemosphere.2013.03.044.

[108] D. Cheng, X. Liu, L. Wang, W. Gong, G. Liu, W. Fu, M. Cheng, Seasonal variation and sedimentwater exchange of antibiotics in a shallower large lake in North China, Sci. Total Environ. 476477 (2014) 266-275. doi:10.1016/j.scitotenv.2014.01.010.

[109] L.-J. Zhou, G.-G. Ying, J.-L. Zhao, J.-F. Yang, L. Wang, B. Yang, S. Liu, Trends in the occurrence of human and veterinary antibiotics in the sediments of the Yellow River, Hai River and Liao River in northern China, Environ. Pollut. 159 (2011) 1877-1885. doi:10.1016/j.envpol.2011.03.034.

[110] M. Schaffer, T. Licha, A framework for assessing the retardation of organic molecules in groundwater: Implications of the species distribution for the sorption-influenced transport, Sci. Total Environ. 524-525 (2015) 187-194. doi:10.1016/j.scitotenv.2015.04.006.

[111] L. Ge, J. Chen, X. Qiao, J. Lin, X. Cai, Light-Source-Dependent Effects of Main Water Constituents on Photodegradation of Phenicol Antibiotics: Mechanism and Kinetics, Environ. Sci. Technol. 43 (2009) 3101-3107. doi:10.1021/es8031727.

[112] R. Li, C. Zhao, B. Yao, D. Li, S. Yan, K.E. O'Shea, W. Song, Photochemical Transformation of Aminoglycoside Antibiotics in Simulated Natural Waters, Environ. Sci. Technol. 50 (2016) 29212930. doi:10.1021/acs.est.5b05234.

[113] L. Ge, J. Chen, X. Wei, S. Zhang, X. Qiao, X. Cai, Q. Xie, Aquatic Photochemistry of Fluoroquinolone Antibiotics: Kinetics, Pathways, and Multivariate Effects of Main Water Constituents, Environ. Sci. Technol. 44 (2010) 2400-2405. doi:10.1021/es902852v.

[114] S. Babić, M. Periša, I. Škorić, Photolytic degradation of norfloxacin, enrofloxacin and ciprofloxacin in various aqueous media, Chemosphere. 91 (2013) 1635-1642. doi:10.1016/j.chemosphere.2012.12.072.

[115] Y. Chen, C. Hu, J. Qu, M. Yang, Photodegradation of tetracycline and formation of reactive oxygen species in aqueous tetracycline solution under simulated sunlight irradiation, J. Photochem. Photobiol. Chem. 197 (2008) 81-87. doi:10.1016/j.jphotochem.2007.12.007.

[116] D. Prabhakaran, P. Sukul, M. Lamshöft, M.A. Maheswari, S. Zühlke, M. Spiteller, Photolysis of difloxacin and sarafloxacin in aqueous systems, Chemosphere. 77 (2009) 739-746. doi:10.1016/j.chemosphere.2009.08.031.

[117] Y. Li, J. Niu, W. Wang, Photolysis of Enrofloxacin in aqueous systems under simulated sunlight irradiation: Kinetics, mechanism and toxicity of photolysis products, Chemosphere. 85 (2011) 892-897. doi:10.1016/j.chemosphere.2011.07.008.

[118] M. Sturini, A. Speltini, F. Maraschi, L. Pretali, A. Profumo, E. Fasani, A. Albini, R. Migliavacca, E. Nucleo, Photodegradation of fluoroquinolones in surface water and antimicrobial activity of the photoproducts, Water Res. 46 (2012) 5575-5582. doi:10.1016/j.watres.2012.07.043.

[119] Y. Li, J. Niu, E. Shang, M. Zheng, T. Luan, Effects of nitrate and humic acid on enrofloxacin photolysis in an aqueous system under three light conditions: kinetics and mechanism, Environ. Chem. 11 (2014) 333. doi:10.1071/EN13192.

[120] R. Xuan, L. Arisi, Q. Wang, S.R. Yates, K.C. Biswas, Hydrolysis and photolysis of oxytetracycline in aqueous solution, J. Environ. Sci. Health Part B. 45 (2009) 73-81. doi:10.1080/03601230903404556.

[121] S. Bahnmüller, U. von Gunten, S. Canonica, Sunlight-induced transformation of sulfadiazine and sulfamethoxazole in surface waters and wastewater effluents, Water Res. 57 (2014) 183-192. doi:10.1016/j.watres.2014.03.019.

[122] B. Xu, D. Mao, Y. Luo, L. Xu, Sulfamethoxazole biodegradation and biotransformation in the water-sediment system of a natural river, Bioresour. Technol. 102 (2011) 7069-7076. doi:10.1016/j.biortech.2011.04.086. 
[123] M. Radke, C. Lauwigi, G. Heinkele, T.E. Mürdter, M. Letzel, Fate of the Antibiotic Sulfamethoxazole and Its Two Major Human Metabolites in a Water Sediment Test, Environ. Sci. Technol. 43 (2009) 3135-3141. doi:10.1021/es900300u.

[124] T. Su, H. Deng, J.P. Benskin, M. Radke, Biodegradation of sulfamethoxazole phototransformation products in a water/sediment test, Chemosphere. 148 (2016) 518-525. doi:10.1016/j.chemosphere.2016.01.049.

[125] E. Adamek, W. Baran, A. Sobczak, Assessment of the biodegradability of selected sulfa drugs in two polluted rivers in Poland: Effects of seasonal variations, accidental contamination, turbidity and salinity, J. Hazard. Mater. 313 (2016) 147-158. doi:10.1016/j.jhazmat.2016.03.064.

[126] K. Kümmerer, ed., Pharmaceuticals in the environment: sources, fate, effects and risks ; with 62 tables, 3., rev. and enl. ed, Springer, Berlin, 2008.

[127] A. Białk-Bielińska, S. Stolte, M. Matzke, A. Fabiańska, J. Maszkowska, M. Kołodziejska, B. Liberek, P. Stepnowski, J. Kumirska, Hydrolysis of sulphonamides in aqueous solutions, J. Hazard. Mater. 221-222 (2012) 264-274. doi:10.1016/j.jhazmat.2012.04.044.

[128] M.J. García-Galán, M.S. Díaz-Cruz, D. Barceló, Kinetic studies and characterization of photolytic products of sulfamethazine, sulfapyridine and their acetylated metabolites in water under simulated solar irradiation, Water Res. 46 (2012) 711-722. doi:10.1016/j.watres.2011.11.035.

[129] N.D.H. Khaleel, W.M.M. Mahmoud, G.M. Hadad, R.A. Abdel-Salam, K. Kümmerer, Photolysis of sulfamethoxypyridazine in various aqueous media: Aerobic biodegradation and identification of photoproducts by LC-UV-MS/MS, J. Hazard. Mater. 244-245 (2013) 654-661. doi:10.1016/j.jhazmat.2012.10.059.

[130] X.-Z. Niu, J. Glady-Croué, J.-P. Croué, Photodegradation of sulfathiazole under simulated sunlight: Kinetics, photo-induced structural rearrangement, and antimicrobial activities of photoproducts, Water Res. 124 (2017) 576-583. doi:10.1016/j.watres.2017.08.019.

[131] K.H. Wammer, K.C. Anderson, P.R. Erickson, S. Kliegman, M.E. Moffatt, S.M. Berg, J.A. Heitzman, N.C. Pflug, K. McNeill, D. Martinovic-Weigelt, R. Abagyan, D.M. Cwiertny, E.P. Kolodziej, Environmental Photochemistry of Altrenogest: Photoisomerization to a Bioactive Product with Increased Environmental Persistence via Reversible Photohydration, Environ. Sci. Technol. 50 (2016) 7480-7488. doi:10.1021/acs.est.6b02608.

[132] Z. Ye, H.S. Weinberg, M.T. Meyer, Trace Analysis of Trimethoprim and Sulfonamide, Macrolide, Quinolone, and Tetracycline Antibiotics in Chlorinated Drinking Water Using Liquid Chromatography Electrospray Tandem Mass Spectrometry, Anal. Chem. 79 (2007) 1135-1144. doi:10.1021/ac060972a.

[133] H.W. Leung, L. Jin, S. Wei, M.M.P. Tsui, B. Zhou, L. Jiao, P.C. Cheung, Y.K. Chun, M.B. Murphy, P.K.S. Lam, Pharmaceuticals in Tap Water: Human Health Risk Assessment and Proposed Monitoring Framework in China, Environ. Health Perspect. 121 (2013) 839-846. doi:10.1289/ehp.1206244.

[134] N. Li, K.W.K. Ho, G.-G. Ying, W.-J. Deng, Veterinary antibiotics in food, drinking water, and the urine of preschool children in Hong Kong, Environ. Int. 108 (2017) 246-252. doi:10.1016/j.envint.2017.08.014.

[135] M.R. Boleda, M.T. Galceran, F. Ventura, Behavior of pharmaceuticals and drugs of abuse in a drinking water treatment plant (DWTP) using combined conventional and ultrafiltration and reverse osmosis (UF/RO) treatments, Environ. Pollut. 159 (2011) 1584-1591. doi:10.1016/j.envpol.2011.02.051.

[136] N. Cimetiere, I. Soutrel, M. Lemasle, A. Laplanche, A. Crocq, Standard addition method for the determination of pharmaceutical residues in drinking water by SPE-LC-MS/MS, Environ. Technol. 34 (2013) 3031-3041. doi:10.1080/09593330.2013.800563.

[137] M. Gros, S. Rodríguez-Mozaz, D. Barceló, Fast and comprehensive multi-residue analysis of a broad range of human and veterinary pharmaceuticals and some of their metabolites in surface and treated waters by ultra-high-performance liquid chromatography coupled to quadrupolelinear ion trap tandem mass spectrometry, J. Chromatogr. A. 1248 (2012) 104-121. doi:10.1016/j.chroma.2012.05.084. 
[138] T. Qiao, Z. Yu, X. Zhang, D.W.T. Au, Occurrence and fate of pharmaceuticals and personal care products in drinking water in southern China, J. Environ. Monit. 13 (2011) 3097. doi:10.1039/c1em10318k.

[139] E. Vulliet, C. Cren-Olivé, M.-F. Grenier-Loustalot, Occurrence of pharmaceuticals and hormones in drinking water treated from surface waters, Environ. Chem. Lett. 9 (2011) 103-114. doi:10.1007/s10311-009-0253-7.

[140] P. Paíga, L.H.M.L.M. Santos, C. Delerue-Matos, Development of a multi-residue method for the determination of human and veterinary pharmaceuticals and some of their metabolites in aqueous environmental matrices by SPE-UHPLC-MS/MS, J. Pharm. Biomed. Anal. 135 (2017) 75-86. doi:10.1016/j.jpba.2016.12.013.

[141] M.L. Castillo-García, M.P. Aguilar-Caballos, A. Gómez-Hens, Determination of veterinary penicillin antibiotics by fast high-resolution liquid chromatography and luminescence detection, Talanta. 170 (2017) 343-349. doi:10.1016/j.talanta.2017.04.032.

[142] K.V. Plakas, A.J. Karabelas, Removal of pesticides from water by NF and RO membranes - A review, Desalination. 287 (2012) 255-265. doi:10.1016/j.desal.2011.08.003.

[143] D. Dolar, A. Vuković, D. Ašperger, K. Košutić, Effect of water matrices on removal of veterinary pharmaceuticals by nanofiltration and reverse osmosis membranes, J. Environ. Sci. 23 (2011) 1299-1307. doi:10.1016/S1001-0742(10)60545-1.

[144] X. Zhang, W. Guo, H.H. Ngo, H. Wen, N. Li, W. Wu, Performance evaluation of powdered activated carbon for removing 28 types of antibiotics from water, J. Environ. Manage. 172 (2016) 193-200. doi:10.1016/j.jenvman.2016.02.038.

[145] J. Rivera-Utrilla, M. Sánchez-Polo, M.Á. Ferro-García, G. Prados-Joya, R. Ocampo-Pérez, Pharmaceuticals as emerging contaminants and their removal from water. A review, Chemosphere. 93 (2013) 1268-1287. doi:10.1016/j.chemosphere.2013.07.059.

[146] N.K. Shammas, L.K. Wang, G.M. Fair, J.C. Geyer, D.A. Okun, Water engineering: hydraulics, distribution and treatment, 1. ed, Wiley, Hoboken, NJ, 2016.

[147] T. Lin, S. Yu, W. Chen, Occurrence, removal and risk assessment of pharmaceutical and personal care products (PPCPs) in an advanced drinking water treatment plant (ADWTP) around Taihu Lake in China, Chemosphere. 152 (2016) 1-9. doi:10.1016/j.chemosphere.2016.02.109.

[148] K.-J. Choi, S.-G. Kim, S.-H. Kim, Removal of antibiotics by coagulation and granular activated carbon filtration, J. Hazard. Mater. 151 (2008) 38-43. doi:10.1016/j.jhazmat.2007.05.059.

[149] F. Dong, C. Li, G. He, X. Chen, X. Mao, Kinetics and degradation pathway of sulfamethazine chlorination in pilot-scale water distribution systems, Chem. Eng. J. 321 (2017) 521-532. doi:10.1016/j.cej.2017.03.130.

[150] V.M.F. Frade, M. Dias, A.C.S.C. Teixeira, M.S.A. Palma, Environmental contamination by fluoroquinolones, Braz. J. Pharm. Sci. 50 (2014) 41-54. doi:10.1590/S198482502011000100004.

[151] T. Garoma, S.K. Umamaheshwar, A. Mumper, Removal of sulfadiazine, sulfamethizole, sulfamethoxazole, and sulfathiazole from aqueous solution by ozonation, Chemosphere. 79 (2010) 814-820. doi:10.1016/j.chemosphere.2010.02.060.

[152] H.W. Sun, Comparison on Permanganate and Ozone as Pre-Oxidation Agents, Adv. Mater. Res. 955-959 (2014) 3408-3413. doi:10.4028/www.scientific.net/AMR.955-959.3408.

[153]X. Zhong, C. Cui, S. Yu, Seasonal evaluation of disinfection by-products throughout two full-scale drinking water treatment plants, Chemosphere. 179 (2017) 290-297. doi:10.1016/j.chemosphere.2017.03.103.

[154] W. Ben, Y. Shi, W. Li, Y. Zhang, Z. Qiang, Oxidation of sulfonamide antibiotics by chlorine dioxide in water: Kinetics and reaction pathways, Chem. Eng. J. 327 (2017) 743-750. doi:10.1016/j.cej.2017.06.157.

[155] A. Azzouz, E. Ballesteros, Influence of seasonal climate differences on the pharmaceutical, hormone and personal care product removal efficiency of a drinking water treatment plant, Chemosphere. 93 (2013) 2046-2054. doi:10.1016/j.chemosphere.2013.07.037. 
[156] A.M.D. de Oliveira, M.G. Maniero, C. Rodrigues-Silva, J.R. Guimarães, Antimicrobial activity and acute toxicity of ozonated lomefloxacin solution, Environ. Sci. Pollut. Res. 24 (2017) 6252-6260. doi:10.1007/s11356-016-8319-0.

[157] M. SUI, Kinetics of Ozonation of Typical Sulfonamides in Water, Biomed Env. Sci. 24 (2011) 255260.

[158] J. Liu, Q. Sun, C. Zhang, H. Li, W. Song, N. Zhang, X. Jia, Removal of typical antibiotics in the advanced treatment process of productive drinking water, Desalination Water Treat. 57 (2016) 11386-11391. doi:10.1080/19443994.2015.1040848.

[159] R. Daghrir, P. Drogui, Tetracycline antibiotics in the environment: a review, Environ. Chem. Lett. 11 (2013) 209-227. doi:10.1007/s10311-013-0404-8.

[160] H. Fu, X. Li, J. Wang, P. Lin, C. Chen, X. Zhang, I.H. (Mel) Suffet, Activated carbon adsorption of quinolone antibiotics in water: Performance, mechanism, and modeling, J. Environ. Sci. 56 (2017) 145-152. doi:10.1016/j.jes.2016.09.010.

[161] S. Metsämuuronen, M. Sillanpää, A. Bhatnagar, M. Mänttäri, Natural Organic Matter Removal from Drinking Water by Membrane Technology, Sep. Purif. Rev. 43 (2014) 1-61. doi:10.1080/15422119.2012.712080.

[162] A. Ogutverici, L. Yilmaz, U. Yetis, F.B. Dilek, Triclosan removal by NF from a real drinking water source - Effect of natural organic matter, Chem. Eng. J. 283 (2016) 330-337. doi:10.1016/j.cej.2015.07.065.

[163] I. Koyuncu, O.A. Arikan, M.R. Wiesner, C. Rice, Removal of hormones and antibiotics by nanofiltration membranes, J. Membr. Sci. 309 (2008) 94-101. doi:10.1016/j.memsci.2007.10.010.

[164] M.-Y. Lutskiy, S. Avneri-Katz, N. Zhu, M. Itsko, Z. Ronen, C.J. Arnusch, R. Kasher, A microbiologybased assay for quantification of bacterial early stage biofilm formation on reverse-osmosis and nanofiltration membranes, Sep. Purif. Technol. 141 (2015) 214-220. doi:10.1016/j.seppur.2014.12.003.

[165] S. Navalon, M. Alvaro, H. Garcia, Reaction of chlorine dioxide with emergent water pollutants: Product study of the reaction of three $\beta$-lactam antibiotics with ClO2, Water Res. 42 (2008) 1935-1942. doi:10.1016/j.watres.2007.11.023.

[166] P. Wang, Y.-L. He, C.-H. Huang, Oxidation of fluoroquinolone antibiotics and structurally related amines by chlorine dioxide: Reaction kinetics, product and pathway evaluation, Water Res. 44 (2010) 5989-5998. doi:10.1016/j.watres.2010.07.053.

[167] S. Snowberger, H. Adejumo, K. He, K.P. Mangalgiri, M. Hopanna, A.D. Soares, L. Blaney, Direct Photolysis of Fluoroquinolone Antibiotics at $253.7 \mathrm{~nm}$ : Specific Reaction Kinetics and Formation of Equally Potent Fluoroquinolone Antibiotics, Environ. Sci. Technol. 50 (2016) 9533-9542. doi:10.1021/acs.est.6b01794.

[168] H. Yao, P. Sun, D. Minakata, J.C. Crittenden, C.-H. Huang, Kinetics and Modeling of Degradation of lonophore Antibiotics by UV and UV/ $\mathrm{H}_{2} \mathrm{O}_{2}$, Environ. Sci. Technol. 47 (2013) 4581-4589. doi:10.1021/es3052685.

[169] C. Cui, L. Jin, L. jiang, Q. Han, K. Lin, S. Lu, D. Zhang, G. Cao, Removal of trace level amounts of twelve sulfonamides from drinking water by UV-activated peroxymonosulfate, Sci. Total Environ. 572 (2016) 244-251. doi:10.1016/j.scitotenv.2016.07.183.

[170] P.E. Stackelberg, J. Gibs, E.T. Furlong, M.T. Meyer, S.D. Zaugg, R.L. Lippincott, Efficiency of conventional drinking-water-treatment processes in removal of pharmaceuticals and other organic compounds, Sci. Total Environ. 377 (2007) 255-272. doi:10.1016/j.scitotenv.2007.01.095.

[171] C.J. Houtman, J. Kroesbergen, K. Lekkerkerker-Teunissen, J.P. van der Hoek, Human health risk assessment of the mixture of pharmaceuticals in Dutch drinking water and its sources based on frequent monitoring data, Sci. Total Environ. 496 (2014) 54-62. doi:10.1016/j.scitotenv.2014.07.022. 
[172] B. Le Bot, J.-P. Lucas, F. Lacroix, P. Glorennec, Exposure of children to metals via tap water ingestion at home: Contamination and exposure data from a nationwide survey in France, Environ. Int. 94 (2016) 500-507. doi:10.1016/j.envint.2016.06.009.

[173] S. Fingler, G. Mendaš, M. Dvoršćak, S. Stipičević, ž. Vasilić, V. Drevenkar, Herbicide micropollutants in surface, ground and drinking waters within and near the area of Zagreb, Croatia, Environ. Sci. Pollut. Res. 24 (2017) 11017-11030. doi:10.1007/s11356-016-7074-6.

[174] M. Jiang, L. Wang, R. Ji, Biotic and abiotic degradation of four cephalosporin antibiotics in a lake surface water and sediment, Chemosphere. 80 (2010) 1399-1405. doi:10.1016/j.chemosphere.2010.05.048.

[175] X. Li, W. Zheng, M.L. Machesky, S.R. Yates, M. Katterhenry, Degradation Kinetics and Mechanism of Antibiotic Ceftiofur in Recycled Water Derived from a Beef Farm, J. Agric. Food Chem. 59 (2011) 10176-10181. doi:10.1021/jf202325c.

[176] H. Pouliquen, R. Delépée, M. Larhantec-Verdier, M.-L. Morvan, H. Le Bris, Comparative hydrolysis and photolysis of four antibacterial agents (oxytetracycline oxolinic acid, flumequine and florfenicol) in deionised water, freshwater and seawater under abiotic conditions, Aquaculture. 262 (2007) 23-28. doi:10.1016/j.aquaculture.2006.10.014.

[177] S.M. Mitchell, J.L. Ullman, A.L. Teel, R.J. Watts, Hydrolysis of amphenicol and macrolide antibiotics: Chloramphenicol, florfenicol, spiramycin, and tylosin, Chemosphere. 134 (2015) 504-511. doi:10.1016/j.chemosphere.2014.08.050.

[178] P. Bohn, S.A. Bak, E. Björklund, K.A. Krogh, M. Hansen, Abiotic degradation of antibiotic ionophores, Environ. Pollut. 182 (2013) 177-183. doi:10.1016/j.envpol.2013.06.040.

[179] A. Längin, R. Alexy, A. König, K. Kümmerer, Deactivation and transformation products in biodegradability testing of ß-lactams amoxicillin and piperacillin, Chemosphere. 75 (2009) 347354. doi:10.1016/j.chemosphere.2008.12.032.

[180] S.M. Mitchell, J.L. Ullman, A.L. Teel, R.J. Watts, $\mathrm{pH}$ and temperature effects on the hydrolysis of three $\beta$-lactam antibiotics: Ampicillin, cefalotin and cefoxitin, Sci. Total Environ. 466-467 (2014) 547-555. doi:10.1016/j.scitotenv.2013.06.027.

[181] I. Braschi, S. Blasioli, C. Fellet, R. Lorenzini, A. Garelli, M. Pori, D. Giacomini, Persistence and degradation of new $\beta$-lactam antibiotics in the soil and water environment, Chemosphere. 93 (2013) 152-159. doi:10.1016/j.chemosphere.2013.05.016.

[182] R. Nassar, A. Trivella, S. Mokh, M. Al-Iskandarani, H. Budzinski, P. Mazellier, Photodegradation of sulfamethazine, sulfamethoxypiridazine, amitriptyline, and clomipramine drugs in aqueous media, J. Photochem. Photobiol. Chem. 336 (2017) 176-182. doi:10.1016/j.jphotochem.2016.12.008.

[183] K.A. Loftin, C.D. Adams, M.T. Meyer, R. Surampalli, Effects of lonic Strength, Temperature, and pH on Degradation of Selected Antibiotics, J. Environ. Qual. 37 (2008) 378. doi:10.2134/jeq2007.0230.

[184] D. Hu, J.R. Coats, Aerobic degradation and photolysis of tylosin in water and soil, Environ. Toxicol. Chem. 26 (2007) 884-889.

[185] D. Dolar, Photolysis of enrofloxacin and removal of its photodegradation products from water by reverse osmosis and nanofiltration membranes, Sep. Purification Technol. (2013) 8. 


\section{TABLES AND FIGURES}

FIGURE 1: Concentration ranges (ng/L) of VPRs frequently searched in natural waters $(2007-2017)\left(n^{a} \text { samples }>100\right)^{b}$

Concentration (ng/L)

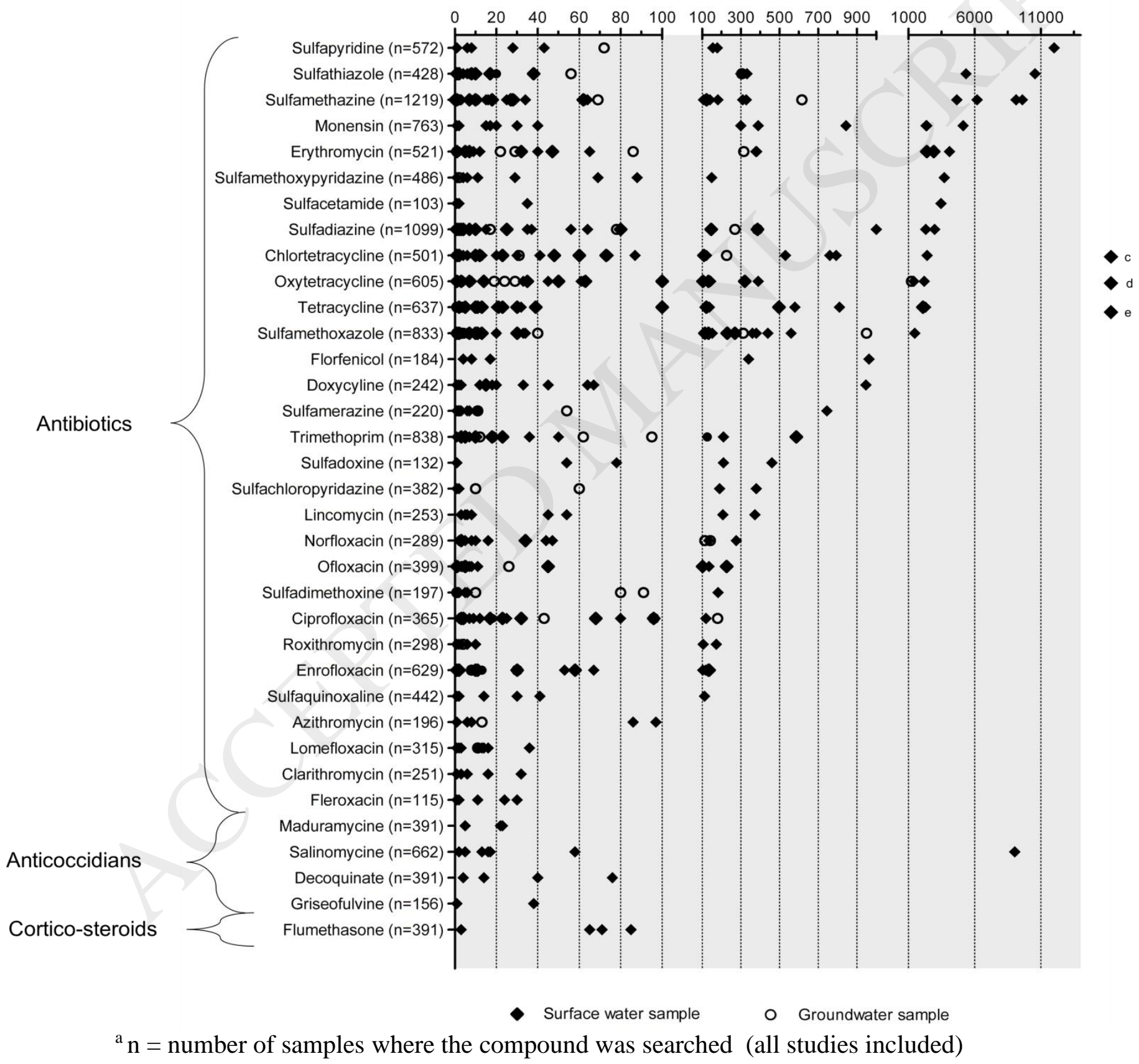


${ }^{\mathrm{b}}$ All details (studies references, studies locations...) can be found in Table S1 and Table S2 in Supplementary Information

${ }^{c}$ Out-of-scale value (Chlortetracycline : $44 \mu \mathrm{g} / \mathrm{L}$ )

${ }^{\mathrm{d}}$ Out-of-scale value (Oxytetracycline : $\left.68 \mu \mathrm{g} / \mathrm{L}\right)$

${ }^{\text {e }}$ Out-of-scale value (Tetracycline : $255 \mu \mathrm{g} / \mathrm{L}$ )

FIGURE 2: Concentration ranges (ng/L) of VPRs less searched in natural waters (20072017) ( $\mathbf{n}^{\mathrm{a}}$ samples $\left.<100\right)^{\mathrm{b}}$

Concentration (ng/L)

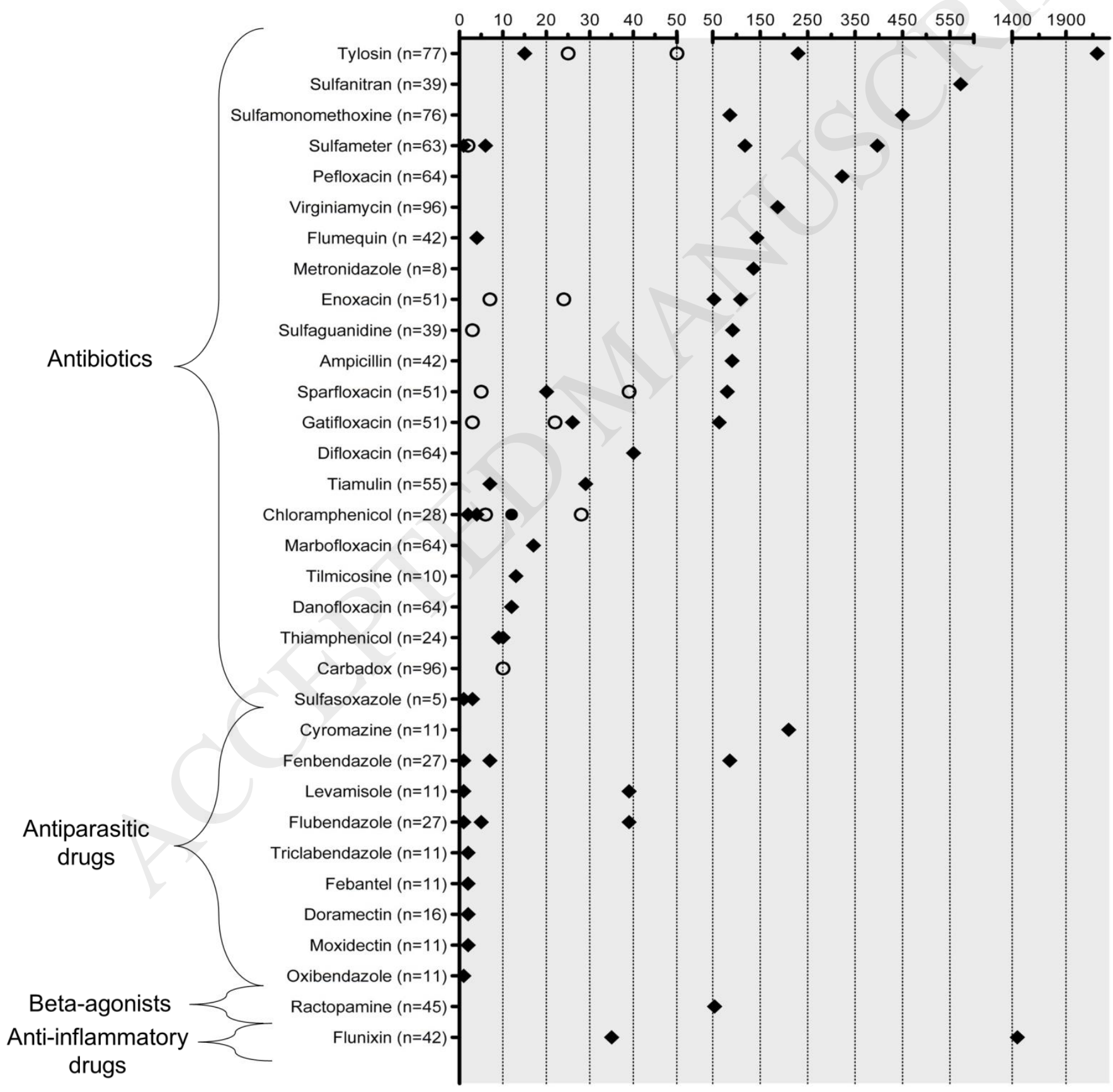


${ }^{\mathrm{a}} \mathrm{n}=\mathrm{n}$ number of samples where the compound was searched (all studies included)

${ }^{\mathrm{b}}$ All details (studies references, studies locations...) can be found in Table S1 and Table S2 in Supplementary Information 
TABLE 1: Sales of VPRs in France [91], Europe [89] and USA [87]

\begin{tabular}{|c|c|c|c|c|c|c|c|c|}
\hline \multicolumn{3}{|c|}{ SALES IN FRANCE IN 2016} & \multicolumn{3}{|c|}{ SALES IN EUROPE IN 2015* } & \multicolumn{3}{|c|}{ SALES IN UNITED STATES IN 2016} \\
\hline Chemical family & $\begin{array}{l}\text { Authorized Compounds } \\
\text { in } 2016\end{array}$ & $\begin{array}{c}\text { Sales (tons of } \\
\text { active ingredient) }\end{array}$ & $\begin{array}{l}\text { Chemical } \\
\text { family }\end{array}$ & $\begin{array}{l}\text { Authorized compounds in } \\
2010-2015\end{array}$ & $\begin{array}{c}\text { Sales (tons of } \\
\text { active ingredient) }\end{array}$ & $\begin{array}{l}\text { Chemical } \\
\text { family }\end{array}$ & $\begin{array}{c}\text { Actively Marketed } \\
\text { Compounds in } 2016\end{array}$ & $\begin{array}{c}\text { Sales (tons of } \\
\text { active ingredient) }\end{array}$ \\
\hline TCs & $\begin{array}{l}\text { Chlortetracycline } \\
\text { Doxycycline } \\
\text { Oxytetracycline }\end{array}$ & 185 & TCs & $\begin{array}{l}\text { Chlortetracycline } \\
\text { Oxytetracycline } \\
\text { Tetracycline } \\
\text { Doxycycline }\end{array}$ & 2723 & TCs & $\begin{array}{l}\text { Chlortetracycline } \\
\text { Oxytetracycline } \\
\text { Tetracycline }\end{array}$ & 5867 \\
\hline SAs & $\begin{array}{l}\text { Sulfadiazine } \\
\text { Sulfamethazine } \\
\text { Sulfadimethoxine } \\
\text { Sulfaguanidine } \\
\text { Sulfamethoxypyridazine } \\
\text { Sulfadoxine }\end{array}$ & 111 & PENs & $\begin{array}{l}\text { Amoxicillin } \\
\text { Ampicillin } \\
\text { Penicillin G } \\
\text { Phenoxymethyl-penicillin } \\
\text { Pheneticillin } \\
\text { Penethamate } \\
\text { Cloxacillin } \\
\text { Dicloxacillin } \\
\text { Nafcillin } \\
\text { Oxacillin } \\
\text { Metampicillin }\end{array}$ & 2072 & Ionophores & $\begin{array}{l}\text { Laidlomycin } \\
\text { Lasalocid } \\
\text { Monensin } \\
\text { Narasin } \\
\text { Salinomycin }\end{array}$ & 4603 \\
\hline PENs & $\begin{array}{l}\text { Amoxicillin } \\
\text { Ampicillin } \\
\text { Penicillin G } \\
\text { Phenoxymethylpenicillin } \\
\text { Cloxacillin }\end{array}$ & 78 & SAs & $\begin{array}{l}\text { Formosulfathiazole } \\
\text { Phthalylsulfathiazole } \\
\text { Sulfacetamide } \\
\text { Sulfachlorpyridazine } \\
\text { Sulfaclozine } \\
\text { Sulfadiazine } \\
\text { Sulfamonomethoxine } \\
\text { Sulfadimethoxine } \\
\text { Sulfamethazine } \\
\text { Sulfadoxine } \\
\text { Sulfafurazole } \\
\text { Sulfaguanidine } \\
\text { Sulfalene } \\
\text { Sulfamerazine } \\
\text { Sulfamethizole } \\
\text { Sulfamethoxazole }\end{array}$ & 978 & Others $* *$ & $\begin{array}{l}\text { Novobiocin } \\
\text { Florfenicol } \\
\text { Ormetoprim } \\
\text { Bambermycins } \\
\text { Avilamycin } \\
\text { Tiamulin } \\
\text { Polymyxin B1 } \\
\text { Bacitracin } \\
\text { Carbadox } \\
\text { Virginiamycin }\end{array}$ & 1235 \\
\hline
\end{tabular}




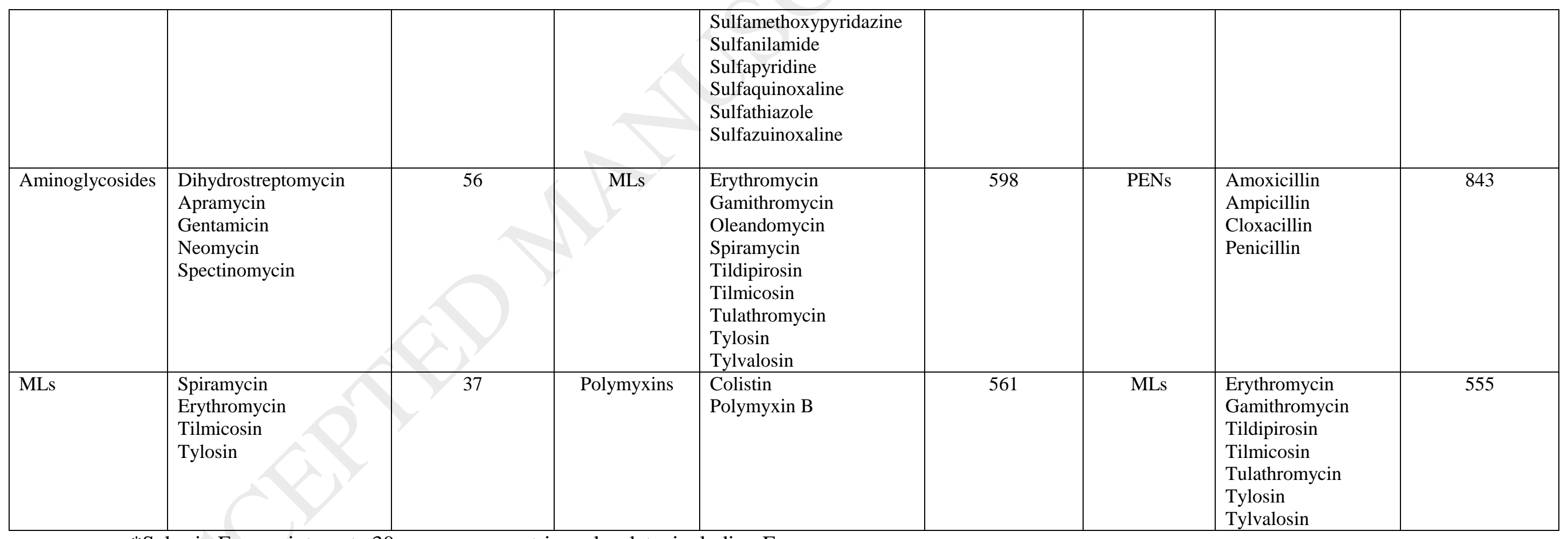

*Sales in Europe integrate 30 european countries sales data, including France

** Others include the following: Aminocoumarins, Amphenicols, Diaminopyrimidines, Glycolipids, Orthosomycins, Pleuromutilins,

Polymyxins, Polypeptides, Quinoxalines, Streptogramins

Acronyms: TCs: Tetracyclines SAs: Sulfonamides PENs: Penicillins MLs: Macrolides

TABLE 2: Sales of VPRs in Korea [95] and Japan [96] in 2015

\begin{tabular}{|c|c|c|c|c|c|}
\hline \multicolumn{2}{|c|}{ MOST SOLD VPs IN KOREA (2015) } & \multicolumn{2}{c|}{ MOST SOLD VPs IN JAPAN (2015) } \\
\hline Chemical family & Compound & Sales of active & Chemical family & Compound & Sales of active \\
\hline
\end{tabular}




\begin{tabular}{|l|l|c|l|l|c|}
\hline & & ingredient (tons) & & & ingredient (tons) \\
\hline TCs & Oxytetracyline & 159 & TCs & Oxytetracycline & 179 \\
\hline
\end{tabular}

\begin{tabular}{l|l} 
SALES IN NEW ZEALAND IN 2014 & SALES IN AUSTRALIA IN 2010
\end{tabular}

\begin{tabular}{|c|c|c|c|c|c|}
\hline PENs & Amoxicillin & 140 & $\mathrm{TCs}$ & Doxycycline & 79 \\
\hline Phenicols & Florfenicol & 92 & $\mathrm{TCs}$ & Chlortetracycline & 76 \\
\hline TCs & Chlortetracycline & 76 & SAs & Sulfamethoxazole & 60 \\
\hline PENs & Ampicillin & 57 & MLs & Tylosin & 48 \\
\hline MLs & Tylosin & 39 & MLs & Erythromycin & 38 \\
\hline Quinolones & Enrofloxacin & 37 & PENs & Ampicillin & 37 \\
\hline SAs & Sulfathiazole & 32 & Pleuromutilins & Tiamulin & 32 \\
\hline SAs & Sulfamethoxazole & 28 & PENs & Amoxicillin & 31 \\
\hline Pleuromutilins & Tiamulin & 18 & Lincosamides & Lincomycin & 29 \\
\hline
\end{tabular}

Acronyms: TCs: Tetracyclines SAs: Sulfonamides PENs: Penicillins MLs: Macrolides

TABLE 3: Sales of VPRs in New-Zealand in 2014 [99] and in Australia in 2010 [98] 


\begin{tabular}{|c|c|c|c|c|c|}
\hline Chemical family & Compound & $\begin{array}{l}\text { Sales of active } \\
\text { ingredient (tons) }\end{array}$ & Chemical family & Compound & $\begin{array}{c}\text { Sales of active } \\
\text { ingredient (tons) }\end{array}$ \\
\hline Polypeptide & Zinc Bacitracin & 23 & Polypeptides & $\begin{array}{l}\text { Zinc Bacitracin } \\
\text { Polymixin B }\end{array}$ & 113 \\
\hline PENs & $\begin{array}{l}\text { Amoxycillin } \\
\text { Benzylpenicillin } \\
\text { Ampicillin } \\
\text { Cloxacillin } \\
\text { Penethamate Hydriodide }\end{array}$ & 14 & TCs & $\begin{array}{l}\text { Chlortetracycline } \\
\text { Doxycycline } \\
\text { Oxytetracycline } \\
\text { Tetracycline }\end{array}$ & 58 \\
\hline TCs & $\begin{array}{l}\text { Chlortetracycline } \\
\text { Oxytetracycline } \\
\text { Doxycycline }\end{array}$ & 9 & MLs + Streptogramins & $\begin{array}{l}\text { Erythromycin } \\
\text { Kitasamycin } \\
\text { Oleandomycin } \\
\text { Tilmicosin } \\
\text { Tulathromycin } \\
\text { Tylosin } \\
\text { Virginiamycin }\end{array}$ & 54 \\
\hline $\begin{array}{l}\text { MLs + } \\
\text { Lincosamides }\end{array}$ & $\begin{array}{l}\text { Clindamycin } \\
\text { Oleandomycin } \\
\text { Erythromycin } \\
\text { Pirlimycin } \\
\text { Tilmicosin } \\
\text { Lincomycin } \\
\text { Spiramycin } \\
\text { Tylosin } \\
\text { Tulathromycin }\end{array}$ & 8 & $\begin{array}{l}\text { PENs + beta- } \\
\text { lactamase inhibitors }\end{array}$ & $\begin{array}{l}\text { Amoxycillin } \\
\text { Ampicillin } \\
\text { Benzathine penicillin } \\
\text { Clavulanic acid } \\
\text { Cloxacillin } \\
\text { Penethamate } \\
\text { Procaine penicillin }\end{array}$ & 26 \\
\hline SAs & $\begin{array}{l}\text { Sulfadiazine } \\
\text { Sulphamethoxazol } \\
\text { Sulphapyridine } \\
\text { Sulphadimethoxine } \\
\text { Sulphamethoxypyridazine } \\
\text { Sulphaquinoxaline }\end{array}$ & 4 & $\begin{array}{l}\text { SAs + } \\
\text { diaminopyrimidine }\end{array}$ & $\begin{array}{l}\text { Phthalylsulfathiazole } \\
\text { Sulfacetamide } \\
\text { Sulfadiazine } \\
\text { Sulfamethazine } \\
\text { Sulfadoxine } \\
\text { Sulfaquinoxaline }\end{array}$ & 13 \\
\hline
\end{tabular}




\begin{tabular}{|l|l|l|l|l|l|}
\hline & Sulphaguanidine & & & Trimethoprim & \\
Sulphanilamide & & & & \\
Sulphathiazole & Sulphamerazine & & & \\
Sulphamethoxypyridazine & & & & \\
Sulphasoxazole & Sulphamethazine & & & \\
& Sulphanilamide & & & \\
Trimethoprim & & & \\
\hline
\end{tabular}

Acronyms: TCs: Tetracyclines SAs: Sulfonamides PENs: Penicillins MLs: Macrolides

TABLE 4: Pseudo-partitioning coefficients water - SPM of VPRs reported in literature

\begin{tabular}{|c|c|c|c|c|}
\hline Chemical family & Molecule & $\begin{array}{c}P-P C_{S P M} \\
\mathrm{a}(\mathrm{L} / \mathrm{kg}) \text { range }^{\mathrm{b}}\end{array}$ & $\begin{array}{c}\text { Mean } P-P C_{S P M} \\
(\mathrm{~L} / \mathrm{kg})\end{array}$ & Reference \\
\hline \multirow{4}{*}{ SAs } & \multirow{2}{*}{ Sulfadiazine } & $5-1167$ & 249 & [101] \\
\hline & & $/^{\mathrm{c}}$ & 102 & {$[45]$} \\
\hline & \multirow{2}{*}{ Sulfamethazine } & $25-4192$ & 1220 & [101] \\
\hline & & I & 1295 & {$[45]$} \\
\hline \multirow{4}{*}{ FQs } & Enrofloxacin & 1 & 5722 & {$[45]$} \\
\hline & \multirow{2}{*}{ Ofloxacin } & $77-13457$ & 3456 & [101] \\
\hline & & I & 3930 & {$[45]$} \\
\hline & Norfloxacin & $96-3325$ & 574 & {$[101]$} \\
\hline \multirow{4}{*}{ TCs } & \multirow{2}{*}{ Oxytetracycline } & $40-5188$ & 1472 & [101] \\
\hline & & I & 35403 & [45] \\
\hline & \multirow{2}{*}{ Tetracycline } & $221-6173$ & 2572 & [101] \\
\hline & & I & 31379 & [45] \\
\hline
\end{tabular}




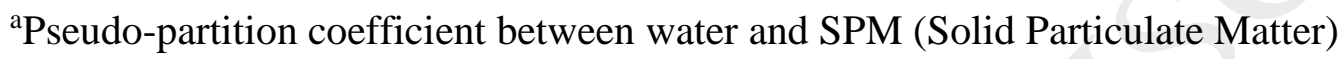

${ }^{b}$ Range: variability among the different samples

${ }^{\mathrm{c}}$ Values are not reported in the study

Acronyms: TCs: Tetracyclines SAs: Sulfonamides FQs: Fluoroquinolones

Table 5: Pseudo-partitioning coefficients water-sediment of VPRs reported in literature

\begin{tabular}{|c|c|c|c|c|}
\hline Chemical family & Molecule & $\begin{array}{c}\mathrm{P}-\mathrm{PC}_{\text {Sed }}^{\mathrm{a}}(\mathrm{L} / \mathrm{kg}) \\
\text { range }^{\mathrm{b}}\end{array}$ & $\begin{array}{c}\text { Mean P- PC } C_{\text {Sed }} \\
(\mathrm{L} / \mathrm{kg})\end{array}$ & Reference \\
\hline & Sulfachloropyridazine & $\begin{array}{c}\text { Not detected }(\mathrm{ND})^{\mathrm{c}} \\
-287\end{array}$ & 254 & [104] \\
\hline & \multirow{2}{*}{ Sulfadiazine } & $518-3279$ & $/^{\mathrm{d}}$ & {$[105]$} \\
\hline & & ND - 332 & 223 & [104] \\
\hline & \multirow{2}{*}{ Sulfadimethoxine } & I & 402 & [106] \\
\hline & & ND - 432 & 312 & [104] \\
\hline & Sulfadoxine & $2-71$ & I & {$[53]$} \\
\hline & \multirow{3}{*}{ Sulfamethazine } & $356-1414$ & I & [105] \\
\hline & & $64-344$ & 225 & [104] \\
\hline & & $42-182$ & I & {$[53]$} \\
\hline & \multirow{2}{*}{ Sulfamethoxazole } & $57-232$ & 185 & [104] \\
\hline & & ND - 22 & 1 & [53] \\
\hline & Sulfamonomethoxine & $27-89$ & I & [53] \\
\hline & Sulfapyridine & $\mathrm{ND}-195^{\mathrm{e}}$ & I & [53] \\
\hline & Sulfathiazole & / & 378 & [106] \\
\hline Diaminopyrimidines & Trimethoprim & $15-789$ & I & [53] \\
\hline \multirow{4}{*}{ MLs } & \multirow{4}{*}{ Erythromycin } & I & 211 & [106] \\
\hline & & $37-1811$ & 1 & [105] \\
\hline & & $45-247$ & 105 & [107] \\
\hline & & ND - 2030 & 1 & [53] \\
\hline
\end{tabular}




\begin{tabular}{|c|c|c|c|c|}
\hline & \multirow{2}{*}{ Roxithromycin } & $168-51934$ & I & [105] \\
\hline & & ND - 1810 & 1 & [53] \\
\hline & Tylosin & 1 & 91 & [106] \\
\hline \multirow{18}{*}{ FQs } & Danofloxacin & ND - 214 & I & [53] \\
\hline & Difloxacin & $31-3530$ & I & [53] \\
\hline & \multirow{3}{*}{ Enrofloxacin } & $36-1457$ & 635 & [45] \\
\hline & & ND - 1266 & 1003 & [104] \\
\hline & & $753-5800$ & I & {$[53]$} \\
\hline & Fleroxacin & $44-2620$ & l & [53] \\
\hline & Lomefloxacin & $63-184$ & I & [53] \\
\hline & Marbofloxacin & $313-1370$ & I & [53] \\
\hline & \multirow{4}{*}{ Norfloxacin } & $31723-68065$ & I & [105] \\
\hline & & $4493-47093$ & 16543 & [108] \\
\hline & & ND - 5440 & / & {$[53]$} \\
\hline & & ND - 1022 & 838 & [104] \\
\hline & \multirow{4}{*}{ Ofloxacin } & $5925-12465$ & 9493 & [108] \\
\hline & & $40-1071$ & 356 & [45] \\
\hline & & $212-5500$ & I & [53] \\
\hline & & ND - 1066 & 771 & [104] \\
\hline & Pefloxacin & ND - 2990 & 1 & [53] \\
\hline & Sarafloxacin & $3380-6510$ & I & [53] \\
\hline \multirow{10}{*}{ TCs } & \multirow{2}{*}{ Chlortetracycline } & 1 & 305 & [106] \\
\hline & & ND - 1018 & 842 & [104] \\
\hline & Doxycycline & $2-18$ & 1 & [53] \\
\hline & \multirow{4}{*}{ Oxytetracycline } & 1 & 1267 & [106] \\
\hline & & / - 1398 & I & [57] \\
\hline & & $277-1398$ & 951 & [108] \\
\hline & & ND - 968 & 786 & [104] \\
\hline & \multirow{3}{*}{ Tetracycline } & I & 1051 & [106] \\
\hline & & / - 1410 & I & [57] \\
\hline & & $768-1227$ & 1020 & [108] \\
\hline
\end{tabular}




\begin{tabular}{|c|c|c|c|c|}
\hline & \multirow{2}{*}{} & $347-10000$ & $/$ & {$[53]$} \\
\cline { 3 - 5 } & & $351-844$ & 687 & {$[104]$} \\
\hline Phenicols & Florfenicol & $<1-3$ & $/$ & {$[53]$} \\
\hline
\end{tabular}

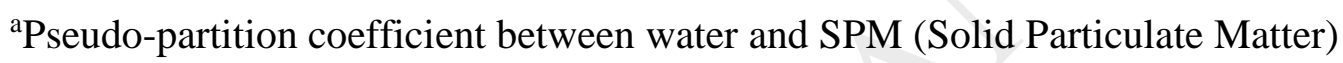

${ }^{\mathrm{b}}$ Range: variability among the different samples

${ }^{\mathrm{c}}$ Not detected

${ }^{\mathrm{d}}$ Values are not reported in the study

Acronyms: TCs: Tetracyclines SAs: Sulfonamides PENs: Penicillins MLs: Macrolides FQs: Fluoroquinolones 
TABLE 6: Fate of VPRs in natural waters

\begin{tabular}{|c|c|c|c|c|c|c|}
\hline Compounds & $\begin{array}{c}\text { Biodegradation } \\
\text { (min-max half-lives) }\end{array}$ & $\begin{array}{c}\text { Hydrolysis } \\
\text { (min-max half-lives) }\end{array}$ & $\begin{array}{c}\text { Direct } \\
\text { photolysis }\end{array}$ & Indirect photolysis & $\begin{array}{c}\text { Min-max } \\
\text { photolysis half-life }\end{array}$ & Photolysis references \\
\hline Altrenogest (hormone) & $/^{\mathrm{a}}$ & / & YES & $\mathbf{N O}^{\mathrm{b}}$ & 27 seconds & [131] \\
\hline Aminoglycosides & I & I & NO & YES & I & [112] \\
\hline Cephalosporins & NO [174] & $\begin{array}{c}\text { YES (2.5-22 days) } \\
{[174,175]} \\
\end{array}$ & l & l & l & \\
\hline Phenicols & I & NO $[176,177]$ & NO & YES & 4.1-7.6 days & [111] \\
\hline FQs & NO $[114,116]$ & NO $[17,114]$ & YES & NO & $7.7-29 \mathrm{~min}$ & {$[17,27,113,114,116,119]$} \\
\hline Ionophores (monensin) & 1 & NO [178] & NO & YES & 4,1 days & [19] \\
\hline $\begin{array}{l}\text { Ionophores } \\
\text { (salinomycine, narasin) }\end{array}$ & l & NO [178] & YES & YES & 53 hours & {$[19,178]$} \\
\hline PENs & NO [179] & $\begin{array}{c}\text { YES (20-27 days) } \\
{[16,180,181]} \\
\end{array}$ & I & I & l & / \\
\hline Quinolones & I & NO [176] & NO & NO & I & {$[176]$} \\
\hline SAs & $\begin{array}{c}\text { YES (17 -153 days) } \\
{[122-124]} \\
\end{array}$ & $\mathbf{N O}^{\mathrm{c}}[127]$ & YES & YES & $13 \mathrm{~min}-14$ hours & {$[18,121,128,130,182]$} \\
\hline MLs & NO [184] & NO [177] & \multicolumn{2}{|c|}{ YES $^{\mathbf{d}}$} & 200 days & {$[184]$} \\
\hline
\end{tabular}

${ }^{\text {a }}$ Data not available

${ }^{\mathrm{b}}$ direct photolysis too fast

'on the 12 studied compounds only 3 were partly and slowly degraded: sulfadiazine, sulfachloropyridazine and sulfamethoxypyridazine 
${ }^{\mathrm{d}}$ No distinction between direct and indirect photolysis

Acronyms: TCs: Tetracyclines SAs: Sulfonamides PENs: Penicillins MLs: Macrolides FQs: Fluoroquinolones

TABLE 7: Occurrence of VPRs in tap water

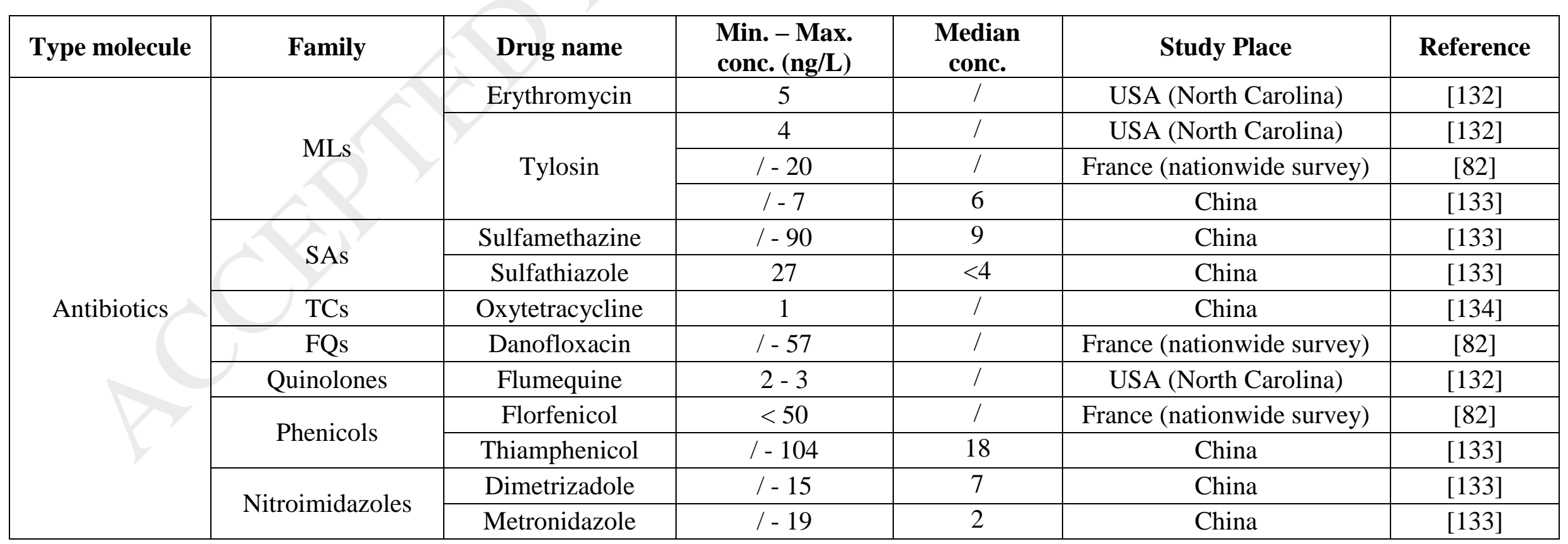

Acronyms: TCs: Tetracyclines SAs: Sulfonamides MLs: Macrolides FQs: Fluoroquinolones 
FIGURE 3: Representation of a drinking water treatment plant

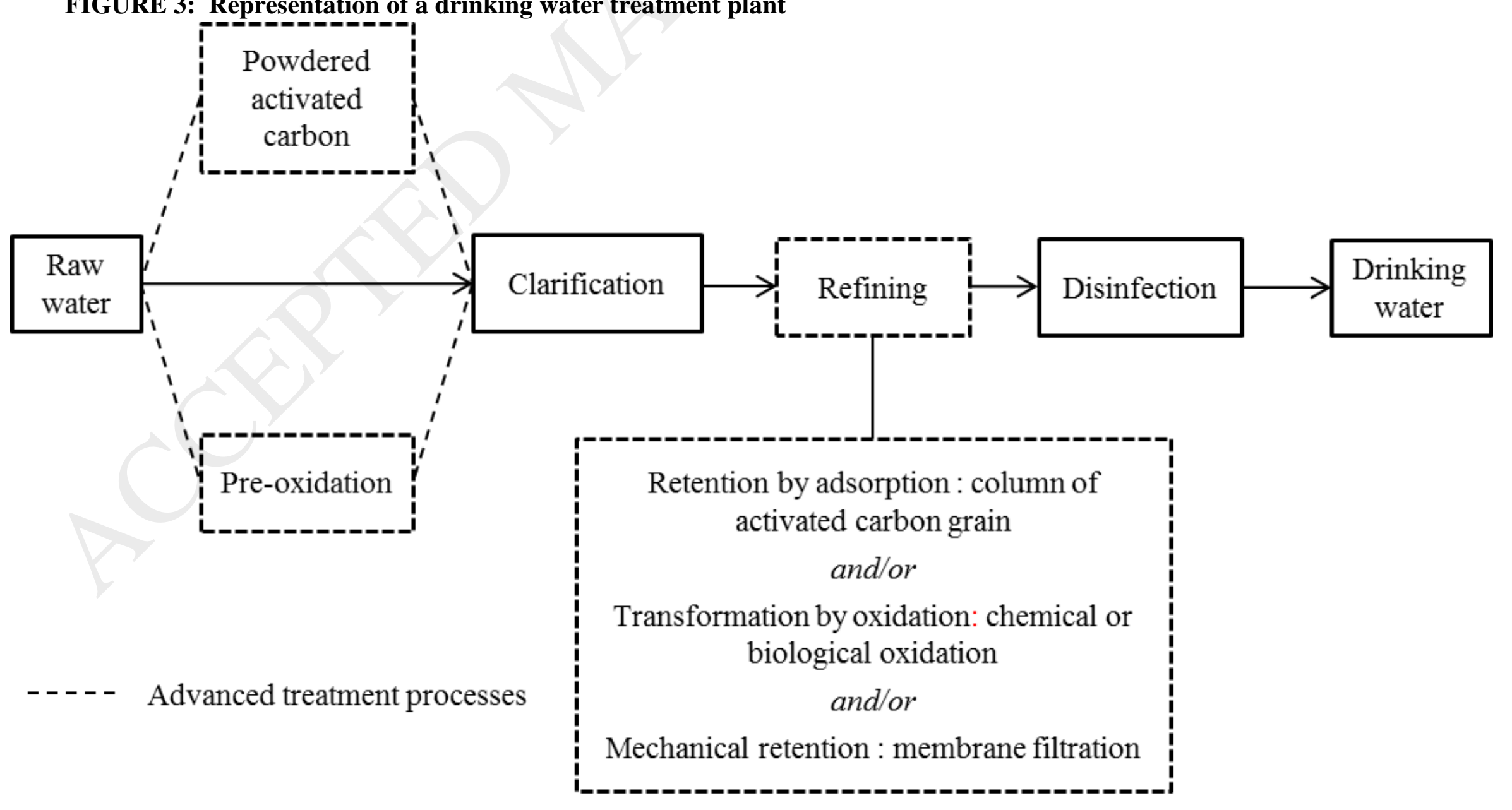

Clarification : coagulation - flocculation -settling - sand filtration 


\begin{tabular}{|l|c|c|c|c|c|c|c|c|c|}
\hline Chemical family & Compound & $\begin{array}{c}\text { Clarification } \\
\text { only }\end{array}$ & $\begin{array}{c}\text { Clarification } \\
+ \text { KMnO4 }\end{array}$ & Chlorination & Ozonation & UV & $\begin{array}{c}\text { Activated } \\
\text { carbon }\end{array}$ & Membranes & References \\
\hline
\end{tabular}

TABLE 8: Removal rates of VPRs during different DWTPs steps 


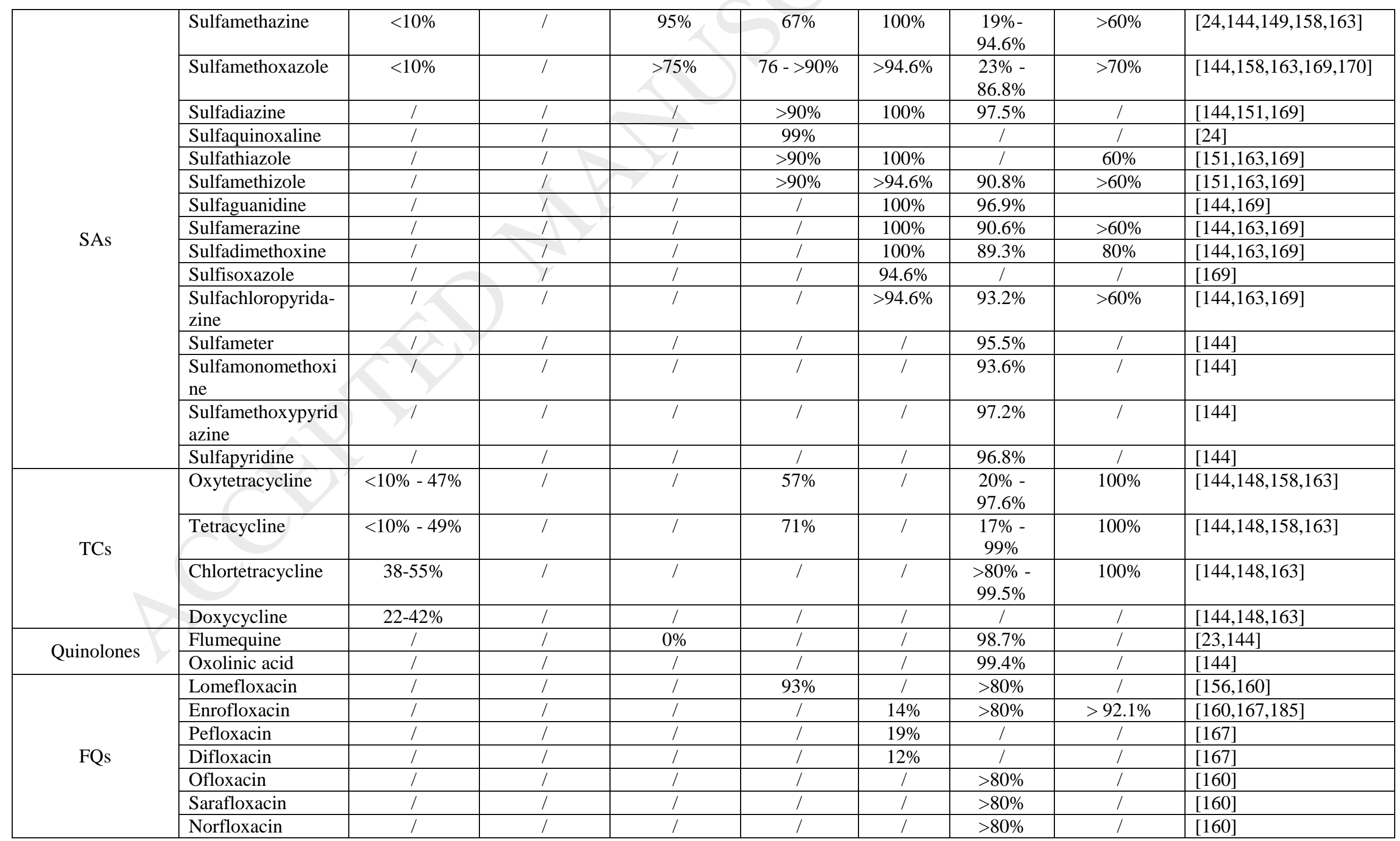




\begin{tabular}{|c|c|c|c|c|c|c|c|c|c|}
\hline \multirow{4}{*}{ MLs } & Erythromycin & $<10 \%$ & I & $>75 \%$ & $100 \%$ & I & $96.3 \%$ & I & {$[144,158,170]$} \\
\hline & Kitasamycin & I & 1 & 1 & 1 & 1 & $99.6 \%$ & 1 & {$[144]$} \\
\hline & Roxithromycin & I & I & 1 & I & I & $95.1 \%$ & 1 & {$[144]$} \\
\hline & Spiramycin & I & I & 1 & I & I & $91.7 \%$ & I & {$[144]$} \\
\hline \multirow{2}{*}{ Phenicols } & Florfenicol & 1 & $87 \%$ & $90 \%^{\mathrm{b}}$ & I & 1 & $98.5 \%$ & I & {$[144,155]$} \\
\hline & Chloramphenicol & 1 & I & $75 \%$ & I & $25 \%$ & $98.4 \%$ & I & {$[22,144]$} \\
\hline \multirow{2}{*}{$\beta$-lactams } & Amoxicillin & $<10 \%$ & 1 & $100 \%$ & $54 \%$ & 1 & $23 \%$ & I & {$[158,165]$} \\
\hline & Penicillin $\mathrm{G}$ & 1 & 1 & $100 \%$ & 1 & 1 & $96.2 \%$ & 1 & {$[144,165]$} \\
\hline \multirow{4}{*}{ Ionophores } & Monensin & 1 & 1 & I & 1 & $100 \%$ & I & 1 & {$[168]$} \\
\hline & Salinomycin & 1 & 1 & 1 & 1 & $100 \%$ & 1 & 1 & {$[168]$} \\
\hline & Nigericin & 1 & 1 & 1 & 1 & $100 \%$ & 1 & 1 & {$[168]$} \\
\hline & Narasin & I & 1 & 1 & 1 & $100 \%$ & 1 & 1 & {$[168]$} \\
\hline NSAIDs $^{\mathrm{a}}$ & Flunixin & 1 & $89 \%$ & 1 & 1 & I & 1 & 1 & {$[155]$} \\
\hline
\end{tabular}

${ }^{a}$ NSAIDs : nonsteroidal anti-inflammatory drugs

${ }^{\mathrm{b}}$ chlorination + filtration

Acronyms: TCs: Tetracyclines SAs: Sulfonamides PENs: Penicillins MLs: Macrolides FQs: Fluoroquinolones 
FIGURE 4: Number of studies dealing with fate of VPRs in natural waters and DWTPs

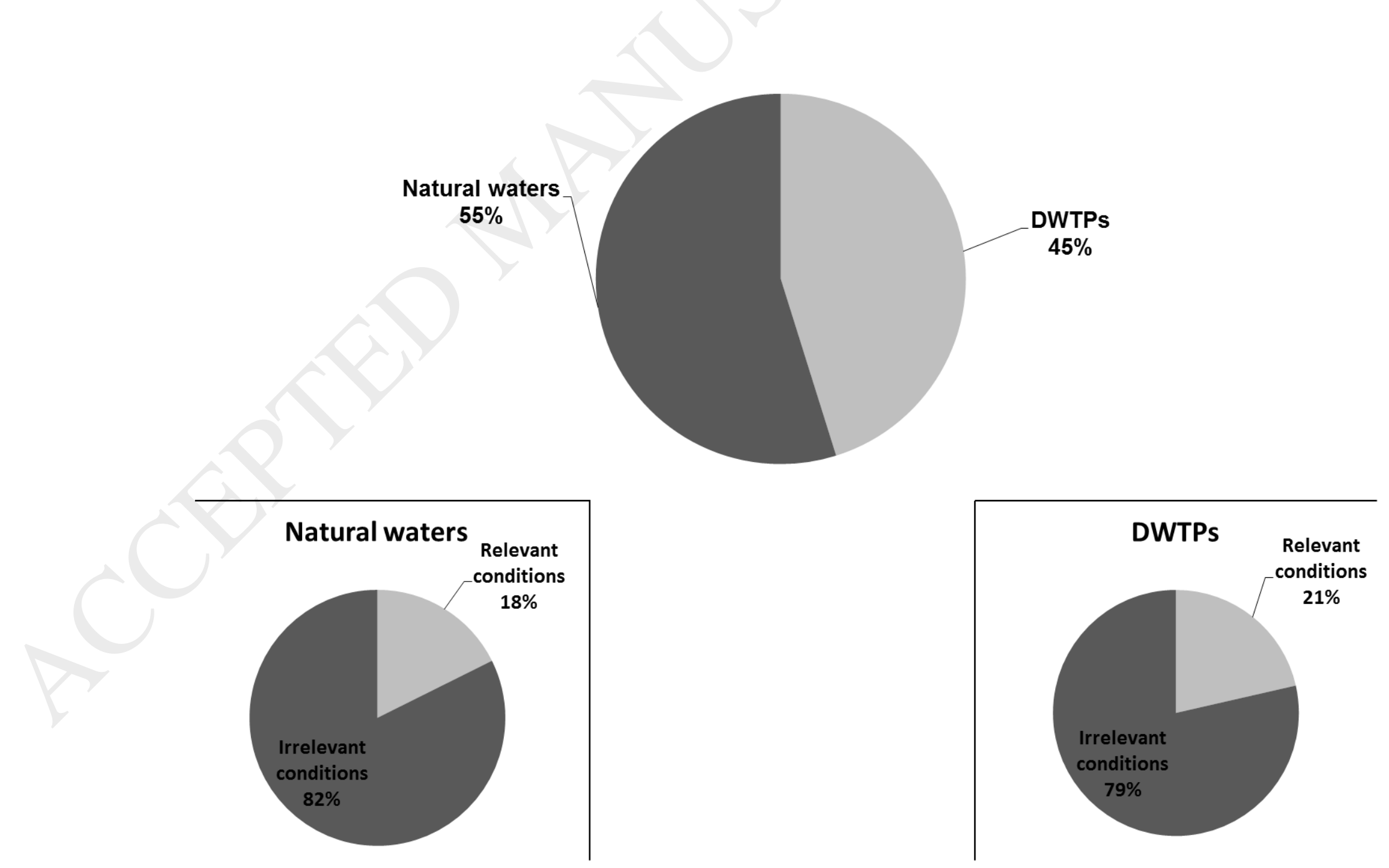

